\title{
Evaluating recovery, cost, and throughput of different concentration methods for SARS-CoV-2 wastewater-based epidemiology
}

4

9 519, Houston, TX 77005, USA

10

11

$14{ }^{\mathrm{d}}$ Houston Health Department, 8000 N. Stadium Dr., Houston, TX 77054

$15 *$ Correspondence to: lauren.stadler@rice.edu 
medRxiv preprint doi: https://doi.org/10.1101/2020.11.27.20238980; this version posted November 30, 2020. The copyright holder for this preprint (which was not certified by peer review) is the author/funder, who has granted medRxiv a license to display the preprint in perpetuity. It is made available under a CC-BY-NC-ND 4.0 International license .

\section{Highlights}

20 Five methods for concentrating SARS-CoV-2 RNA from wastewater evaluated

21 - Method performance characterized via recovery, cost, throughput, and variability

22 - HA filtration with bead beating had highest recovery for comparatively low cost

23 Bovine coronavirus, pepper mild mottle virus assessed as possible recovery controls

24

25

26

27

28

29

30

31

32

33

34 
medRxiv preprint doi: https://doi.org/10.1101/2020.11.27.20238980; this version posted November 30, 2020. The copyright holder for this preprint (which was not certified by peer review) is the author/funder, who has granted medRxiv a license to display the preprint in perpetuity.

It is made available under a CC-BY-NC-ND 4.0 International license .

35 Abstract

36 As the COVID-19 pandemic continues to affect communities across the globe, the need to

37 contain the spread of the outbreaks is of paramount importance. Wastewater monitoring of the

38 SARS-CoV-2 virus, the causative agent responsible for COVID-19, has emerged as a promising

39 tool for health officials to anticipate outbreaks. As interest in wastewater monitoring continues to

40 grow and municipalities begin to implement this approach, there is a need to further identify and

41 evaluate methods used to concentrate SARS-CoV-2 virus RNA from wastewater samples. Here

42 we evaluate the recovery, cost, and throughput of five different concentration methods for

43 quantifying SARS-CoV-2 virus RNA in wastewater samples. We tested the five methods on six

44 different wastewater samples. We also evaluated the use of a bovine coronavirus vaccine as a

45 process control and pepper mild mottle virus as a normalization factor. Of the five methods we

46 tested head-to-head, we found that HA filtration with bead beating performed the best in terms of

47 sensitivity and cost. This evaluation can serve as a guide for laboratories establishing a protocol

48 to perform wastewater monitoring of SARS-CoV-2.

49 Keywords: SARS-CoV-2, Wastewater-based epidemiology, Method evaluation, Virus

50 concentration, Bovine coronavirus, Pepper mild mottle virus 
medRxiv preprint doi: https://doi.org/10.1101/2020.11.27.20238980; this version posted November 30, 2020. The copyright holder for this preprint (which was not certified by peer review) is the author/funder, who has granted medRxiv a license to display the preprint in perpetuity.

It is made available under a CC-BY-NC-ND 4.0 International license .

\section{Introduction}

56 As the COVID-19 pandemic impacts millions worldwide, community monitoring and early

57 detection of disease outbreaks has become of critical importance. While the rate of clinical

58 testing has seen dramatic global increases since the pandemic onset, difficulties in assessing

59 community health via this method remain (Tromberg et al., 2020). These difficulties include the

60 logistics and cost of clinical testing, and a lack of robust contact tracing protocols in most

61 communities. Moreover, the opt-in nature of clinical testing means asymptomatic and

62 symptomatic individuals who decide to forego testing are not accounted for in community

63 prevalence estimates.

64

65 Wastewater-based epidemiology (WBE) is an emerging paradigm for monitoring the community

66 prevalence of SARS-CoV-2 (Hart and Halden, 2020). WBE has already proven to be a viable

67 method for community monitoring of other viral pathogens, including poliovirus, rotavirus,

68 hepatitis A virus, hepatitis E virus, noroviruses, enteroviruses, and adenoviruses, suggesting it

69 could be appropriate for SARS-CoV-2 surveillance (Hellmér et al., 2014; Kamel et al., 2011;

70 Katayama et al., 2008; Lago et al., 2003; McCall et al., 2020). This method of monitoring for

71 SARS-CoV-2 is possible due to fecal shedding of SARS-CoV-2 virus particles and/or virus RNA

72 before, during, and after clinical symptoms manifest in infected individuals (Cheung et al., 2020;

73 Mesoraca et al., 2020; Wölfel et al., 2020). Once feces containing SARS-CoV-2 RNA enters the

74 sewershed, the viral RNA is transported to wastewater treatment plants (WWTP) where it can be

75 detected and quantified. 
medRxiv preprint doi: https://doi.org/10.1101/2020.11.27.20238980; this version posted November 30, 2020. The copyright holder for this preprint (which was not certified by peer review) is the author/funder, who has granted medRxiv a license to display the preprint in perpetuity.

It is made available under a CC-BY-NC-ND 4.0 International license .

77 The detection of SARS-CoV-2 RNA in untreated domestic wastewater has already been reported

78 in numerous studies from countries across the globe including Australia, Italy, the United States,

79 Japan, and more (Ahmed et al., 2020a; La Rosa et al., 2021; Sherchan et al., 2020; Torii et al.,

80 2020). Moreover, concentrations of viral RNA have been shown to correlate with community

81 prevalence of SARS-CoV-2 (Stadler et al., 2020). WBE alleviates roadblocks associated with

82 clinical testing by providing a cheaper, less logistically challenging method for monitoring

83 communities. Importantly, it does not require individuals to opt-in, thereby capturing both

84 symptomatic and asymptomatic individuals. The potential of WBE to inform public health

85 measures by offering trend tracking and prevalence estimates is already of growing interest to

86 local governments and has been put to use by universities to proactively prevent COVID-19

87 outbreaks in campus housing (Colosi et al., 2020; Stadler et al., 2020).

89 The development of rapid, cost-effective, and sensitive methods for quantifying SARS-CoV-2

90 RNA in wastewater are essential for widespread, successful implementation of WBE for SARS-

91 CoV-2. Broadly speaking, the detection and quantification of viral RNA in wastewater is

92 achieved through four steps: (1) wastewater sampling, (2) wastewater concentration, (3) RNA

93 extraction, and (4) RNA quantification. There are multiple methods to choose from for each step,

94 with disparate effects on the performance and practicality of the overall measurement system. As

95 of now, there are no standard or clearly optimal methods for each step and methods are often

96 selected based on a review of the literature, author familiarity with the method, and equipment

97 and/or budget. Therefore, there is a need for the SARS-CoV-2 WBE community to better

98 characterize and directly compare different methods for quantifying SARS-CoV-2 RNA in

99 wastewater. 
medRxiv preprint doi: https://doi.org/10.1101/2020.11.27.20238980; this version posted November 30, 2020. The copyright holder for this preprint (which was not certified by peer review) is the author/funder, who has granted medRxiv a license to display the preprint in perpetuity.

It is made available under a CC-BY-NC-ND 4.0 International license .

101 In this work we characterized different methods for concentrating SARS-CoV-2 RNA from

102 wastewater. We focused on the concentration step because wastewater concentration methods

103 applied for SARS-CoV-2 RNA vary widely from electronegative filtration with bead beating

104 (Ahmed et al., 2020a), electronegative filtration with elution (Sherchan et al., 2020),

105 ultrafiltration (Westhaus et al., 2021), precipitation (La Rosa et al., 2021), ultracentrifugation

106 (Prado et al., 2020), and direct extraction (Crits-Christoph et al., 2020). Moreover, differences in

107 approach, such as sample volume or whether to separate solids by centrifugation can impact

108 measurement outcomes. Without standardization, it has been difficult to compare concentration

109 methods across sites, study their relative strengths and weaknesses, optimize the methods, and

110 understand the biggest sources of RNA loss. Despite these obstacles, our recent study had

111 success in applying empirical adjustment factors to account for differences in SARS-CoV-2

112 RNA measurement methods between two labs (Stadler et al., 2020). The lack of internal

113 standards presents another caveat, as RNA recovery percentages from wastewater samples vary

114 between methods and thus non-normalized viral concentrations may impact comparisons across

115 sites. In order to address this problem, surrogate viruses can be used to estimate the recovery

116 efficiency and quantification of a target virus. Recent studies have used surrogate viruses to

117 estimate SARS-CoV-2 RNA recovery percentages across a variety of methods (Ahmed et al.,

118 2020a; La Rosa et al., 2021; Sherchan et al., 2020; Torii et al., 2020). To our knowledge, only

119 one study has compared SARS-CoV-2 recovery from wastewater across methods in depth, but

120 there were significant differences between compared methods that make it difficult to pinpoint

121 the concentration step or some other factor as the source of differences (Pecson et al., 2020). At

122 least one review compared concentration methods across studies, but there is again other 
medRxiv preprint doi: https://doi.org/10.1101/2020.11.27.20238980; this version posted November 30, 2020. The copyright holder for this preprint (which was not certified by peer review) is the author/funder, who has granted medRxiv a license to display the preprint in perpetuity.

It is made available under a CC-BY-NC-ND 4.0 International license .

123 differences between studies that make it difficult to directly compare the concentration method

124 (La Rosa et al., 2020)

125

126 In this study, we performed a head-to-head comparison of five different concentration methods

127 on samples from six wastewater treatment plants (WWTPs) in Houston, TX. We evaluated the

128 methods by comparing the yields of SARS-CoV-2 RNA and sensitivity of detection by each

129 method. In addition, we compared the recovery of a spiked surrogate virus, bovine coronavirus

130 (BCoV), and the yield of a fecal indicator virus, pepper mild mottle virus (pMMoV). We provide

131 a comprehensive practical summary for each concentration method by outlining start-up cost,

132 consumable cost per sample, throughput time, limit of quantification (LoQ), and the variation in

$133 \mathrm{~N} 1$ and N2 detection between replicate samples. Overall, this study involves an extensive

134 analysis of concentration methods currently in use to quantify SARS-CoV-2 RNA in wastewater,

135 and an examination of $\mathrm{BCoV}$ and $\mathrm{pMMoV}$ as potential control factors.

136

2. Methods

\subsection{Surrogate Preparation}

$139 \mathrm{BCoV}$ was chosen as a surrogate and quality control measure to analyze viral RNA recovery

140 between different concentration methods. Calf Guard (Zoetis) cattle vaccine containing an

141 attenuated strain of the surrogate was used as the source for BCoV. Freeze-dried virus in $3 \mathrm{~mL}$

142 vials was rehydrated in sterile conditions with $1.5 \mathrm{~mL}$ of TE buffer on the morning of sample

143 collection. Multiple vials were rehydrated and combined to prepare enough stock solution to 
medRxiv preprint doi: https://doi.org/10.1101/2020.11.27.20238980; this version posted November 30, 2020. The copyright holder for this preprint (which was not certified by peer review) is the author/funder, who has granted medRxiv a license to display the preprint in perpetuity.

It is made available under a CC-BY-NC-ND 4.0 International license .

144 spike all samples. A $100 \mu \mathrm{L}$ aliquot of $\mathrm{BCoV}$ was immediately stored at $-80 \square$ to later determine

145 the concentration of $\mathrm{BCoV}$ in the stock solution.

\subsection{Wastewater Sampling}

147 Time-weighted composite samples of raw wastewater (influent) were collected every 1 hour for

14824 hours. The collection period began the morning of Monday, October 5, 2020 and ended the

149 morning of Tuesday, October 6, 2020. Wastewater samples from 6 facilities with a range of

150 compositions, as measured by total suspended solids (TSS), carbonaceous biochemical oxygen

151 demand (CBOD), and ammonia (NH4-N), were collected to test the robustness of the different

152 concentration methods (Table 1).

153 concentration methods (Table 1).

154

Wastewater

Treatment Average

Plant Daily Flow

(Anonymized) Rate (MGD)

\begin{tabular}{|c|c|c|c|c|c|}
\hline A & 8.52 & 167,000 & 342 & 126 & 26.2 \\
\hline B & 16.6 & 304,000 & 970 & 120 & 17.4 \\
\hline C & 9.69 & 330,000 & 196 & 155 & 26.2 \\
\hline D & 0.180 & 13,400 & 100 & 155 & 34.2 \\
\hline$E$ & 3.21 & 86,600 & 58.7 & 108 & 30.5 \\
\hline $\mathbf{F}$ & 1.53 & 48,200 & 106 & 201 & 32.0 \\
\hline
\end{tabular}

Table 1. Characteristics of the different wastewater treatment systems. Average daily flow rate

157 was recorded on the day of October 5. Population data was extracted from the 2019 American

158 Community Survey (U.S. Census Bureau, 2019). Composition data were reported from samples 
medRxiv preprint doi: https://doi.org/10.1101/2020.11.27.20238980; this version posted November 30, 2020. The copyright holder for this preprint (which was not certified by peer review) is the author/funder, who has granted medRxiv a license to display the preprint in perpetuity.

It is made available under a CC-BY-NC-ND 4.0 International license .

159 taken between October 5, 2020 to October 6, 2020. All data was provided by the City of

160 Houston (Houston Public Works and Houston Health Department).

1612.3 Wastewater Sample Collection

162 At the end of the sampling period, all samples were transported on ice to a central processing

163 facility. Larger sample volumes were aliquoted into $500 \mathrm{~mL}$, Nalgene ${ }^{\mathrm{TM}}$ Wide-Mouth HDPE

164 Packaging Bottles (3121890016, Thermo Scientific) and spiked with $50 \mu \mathrm{L}$ of BCoV stock

165 solution. Aliquots were transported on ice to Baylor College of Medicine or Rice University and

166 then stored at $4^{\circ} \mathrm{C}$ for further processing.

\section{$167 \quad 2.4$ Wastewater Sample Concentration}

168 The different concentration methods are depicted in Figure 1. Concentration occurred the day

169 following sample collection (Oct. 7). PEG concentration began the day of sample collection to

170 allow the samples to sit overnight (Oct. 6). Technical replicates were performed in triplicate for

171 each concentration method. The direct extraction, HA filtration with bead beating, and

172 ultrafiltration concentration methods were completed at Rice University. The resulting

173 concentrates were immediately transported to Baylor College of Medicine on ice for extraction.

174 HA filtration with elution and PEG methods were completed at Baylor College of Medicine.

175 Concentration methods were split between labs to reduce processing burden and because each

176 lab had more experience with their respective methods. Concentrates were stored at $4^{\circ} \mathrm{C}$ until

177 extraction. 
medRxiv preprint doi: https://doi.org/10.1101/2020.11.27.20238980; this version posted November 30, 2020. The copyright holder for this preprint (which was not certified by peer review) is the author/funder, who has granted medRxiv a license to display the preprint in perpetuity.

It is made available under a CC-BY-NC-ND 4.0 International license .

178

179

180

181

182

183

184

185

186

187

188

189

190

191

192

193

194

195

196

197

198

199

\subsubsection{Direct Extraction}

Approximately $1 \mathrm{~mL}$ of sample was aliquoted into a $1.5 \mathrm{~mL}$ centrifuge tube. The sample was then centrifuged for 5 minutes at $17,000 \mathrm{~g}$ and $4{ }^{\circ} \mathrm{C}$. The supernatant was carefully aspirated without disturbing the pellet and used for extraction.

\subsubsection{HA Filtration with Bead Beating}

Roughly $50 \mathrm{~mL}$ of each sample was aliquoted into $50 \mathrm{~mL}$ conical tubes (1184R09, Thomas

Scientific) and then centrifuged for 10 minutes at $4,100 \mathrm{~g}$ and $4^{\circ} \mathrm{C}$. Prior to sample addition, the assembled MF 3, 300ml Magnetic Filter Holder with lid kit (200300-01, Sterlitech) was attached to the Multi-Vac 600-MS Manifold (180600-01, Sterlitech) and Rocker 800 Oil Free Laboratory Vacuum Pump (167800, Sterlitech) system. Electronegative Microbiological Analysis

Membrane HA Filters (HAWG047S6, Millipore Sigma) were placed into the manifold system with sterile forceps prior to the filtration process. The filters were then washed with approximately $50 \mathrm{~mL}$ of ultrapure water before sample addition. A graduated cylinder was used

to measure $50 \mathrm{~mL}$ of supernatant which was then poured directly into the assembled filter holder. After sample was added into the manifold system, $1 \mathrm{~mL}$ of $1.25 \mathrm{M} \mathrm{MgCl}_{2} \cdot 6 \mathrm{H}_{2} \mathrm{O}(\mathrm{M} 0250-500 \mathrm{G}$, Sigma Aldrich) was added directly to the sample to achieve a final concentration of $25 \mathrm{mM}$. The samples were then gently swirled with a pipette tip to homogenize and allowed to sit for five minutes. The vacuum pump was subsequently turned on and allowed to pull the sample through the filter. After the sample passed through the filter, the vacuum pumps were turned off, the filters were rolled up with sterile forceps, and then placed into a filled bead beating tube $(0.1 \mathrm{~mm}$ diameter glass beads, Ca. No.: 11079101, BioSpec. Bead beating tube, Ca. No: 02-682-558, Fisher Scientific). 
medRxiv preprint doi: https://doi.org/10.1101/2020.11.27.20238980; this version posted November 30, 2020. The copyright holder for this preprint (which was not certified by peer review) is the author/funder, who has granted medRxiv a license to display the preprint in perpetuity.

It is made available under a CC-BY-NC-ND 4.0 International license .

200

201 The beginning of the HA filtration with elution method was similar to HA filtration with bead

beating. However, centrifugation for the elution method was completed for 1 minute at $3,000 \mathrm{~g}$

203

204

205

206

207

208

209

210

211

212

213 collected from the setup. For concentration calculation purposes, the virus was treated as eluting

214 into $2.5 \mathrm{~mL}$.

215

216

217

218

219

220

221

222

and $4^{\circ} \mathrm{C}$. Furthermore, the use of EZ-Fit ${ }^{\mathrm{TM}}$ Filtration Unit (EFHAW100B, Millipore Sigma) is

unique to the elution method. These are sterile, single use filter holders that come with the same electronegative filters used in HA filtration with bead beating. These units were used to facilitate

the elution aspect of the elution method. The major divergence from HA filtration with bead

beating is how the captured virus was recovered from the filters after filtration. After filtration,

filters were carefully flipped over with sterile forceps and placed back into the filter holder.

Next, $5 \mathrm{~mL}$ of $1 \mathrm{mM} \mathrm{NaOH}$ (S318-100, Fisher Scientific) eluent was placed on top of the

inverted filter. The back of a EZ-Fit Filtration Unit was then used to push the eluent through the

filter and into a $15 \mathrm{~mL}$ conical tube (1184R08, Thomas Scientific) containing $12.5 \mu \mathrm{L}$ of 100

$\mathrm{mM} \mathrm{H}_{2} \mathrm{SO}_{4}$ (A300-212, Fisher Scientific) to neutralize the $\mathrm{NaOH}$. Roughly $2.5 \mathrm{~mL}$ of eluent was

2.5 mL.

\subsubsection{PEG precipitation}

Solids were first removed by centrifuging wastewater in $500 \mathrm{~mL}$ centrifuge bottles (47735-696,

VWR) for 15 minutes at $7,140 \mathrm{~g}$ and $4^{\circ} \mathrm{C}$. The supernatant was then filtered through $0.22 \mu \mathrm{m}$

Steritop Threaded Bottle Top Filters (SCGPS05RE, Millipore) into glass bottles. Then, $200 \mathrm{~mL}$

of sample was transferred into a new sterile $500 \mathrm{~mL}$ bottle. Next, $16 \mathrm{~g}$ of PEG $8000(8 \% \mathrm{w} / \mathrm{v})$

(VWRV0159-1KG, VWR) and $5.844 \mathrm{~g}$ of $\mathrm{NaCl}(0.5 \mathrm{M})$ (S271-1, Fisher Chemical) were added

to the bottle. The solution was then inverted, gently shaken by hand, and allowed to precipitate

overnight at $4^{\circ} \mathrm{C}$. The following day, the sample was centrifuged for 30 minutes at $16,900 \mathrm{~g}$ and 
medRxiv preprint doi: https://doi.org/10.1101/2020.11.27.20238980; this version posted November 30, 2020. The copyright holder for this preprint (which was not certified by peer review) is the author/funder, who has granted medRxiv a license to display the preprint in perpetuity.

It is made available under a CC-BY-NC-ND 4.0 International license .

$2234^{\circ} \mathrm{C}$. The supernatant was then poured off and the pellet was resuspended in $2 \mathrm{~mL}$ of $1 \mathrm{X}$ PBS

224 solution $(0.01 \mathrm{M})$. The $1 \mathrm{X}$ PBS solution $(0.01 \mathrm{M})$ was prepared with $1.096 \mathrm{~g} \mathrm{Na}_{2} \mathrm{HPO}_{4}(\mathrm{~S} 375-$

225 500, Fisher Chemical), $0.3148 \mathrm{~g} \mathrm{H}_{2} \mathrm{PO}_{4} \mathrm{Na}^{\circ} \mathrm{H}_{2} \mathrm{O}$ (S369-500, Fisher Chemical), and $8.5 \mathrm{~g} \mathrm{NaCl}$

226 (BP358-10, Fisher Chemical) per liter in ultrapure water and subsequently passed through a 0.22

$227 \mu \mathrm{M}$ filter into a sterile container. $1 \mathrm{~mL}$ of each suspension was then aliquoted into $1.5 \mathrm{~mL}$

228 microcentrifuge tubes.

\subsubsection{Ultrafiltration}

230 Roughly $50 \mathrm{~mL}$ of each sample was aliquoted into $50 \mathrm{~mL}$ conical tubes. The conical tubes were

231 then centrifuged for 10 minutes at $4,100 \mathrm{~g}$ and $4{ }^{\circ} \mathrm{C} .50 \mathrm{~mL}$ of solids-free supernatant was then

232 transferred to another $50 \mathrm{~mL}$ conical tube and stored on ice until further processing. The

233 Amicon ${ }^{\circledR}$ Pro Purification System with 100kDa Amicon ${ }^{\circledR}$ Ultra-0.5 Devices (ACS510024,

234 Millipore Sigma) were filled with $15 \mathrm{~mL}$ of ultrapure water and centrifuged for 8 minutes at

$2351,900 \mathrm{~g}$ and $4^{\circ} \mathrm{C}$. Flow through and residual concentrate were poured out. Approximately $15 \mathrm{~mL}$

236 of supernatant was then loaded into each ultrafiltration device. The ultrafiltration devices were

237 then centrifuged for 10 minutes at $4,100 \mathrm{~g}$ and $4{ }^{\circ} \mathrm{C}$. Flow through was discarded, and additional

238 sample added to reach the volume limit of the ultrafiltration devices. The centrifugation and

239 discarding process was repeated until each sample had completely passed through the

240 ultrafiltration devices. As the ultrafiltration approached completion, centrifugation intervals of 3

241 minutes and 5 minutes were used to end with a final concentrate volume of approximately 1.5

$242 \mathrm{~mL}$. Concentrate was pipetted from the ultrafiltration devices into $2 \mathrm{~mL}$ microcentrifuge tubes.

243 Microcentrifuge tubes containing the sample were weighed to calculate total volume of

244 concentrate. 
medRxiv preprint doi: https://doi.org/10.1101/2020.11.27.20238980; this version posted November 30, 2020. The copyright holder for this preprint (which was not certified by peer review) is the author/funder, who has granted medRxiv a license to display the preprint in perpetuity.

It is made available under a CC-BY-NC-ND 4.0 International license .

\subsection{RNA Extraction}

246 Liquid samples were extracted with the chemagic ${ }^{\mathrm{TM}}$ Prime Viral DNA/RNA 300 Kit H96 (CMG-

247 1433, PerkinElmer) following manufacturer protocol. $300 \mu \mathrm{L}$ of liquid concentrate was

248 extracted into $100 \mu \mathrm{L}$ of sterile, nuclease free water. Extraction occurred the day following

249 concentration for all liquid samples.

251 Bead beating tubes containing filters from the HA Filtration with bead beating concentration 252 method were extracted by first adding $600 \mu \mathrm{L}$ of lysis buffer from the chemagic kit. The 253 samples were then bead beaten on a FastPrep-24 ${ }^{\mathrm{TM}} 5 \mathrm{G}$ bead beater (116005500, MP Biomedical)

254 for 1 minute at $5 \mathrm{~m} / \mathrm{s}$, placed on ice for 2 minutes, bead beaten for 1 minute at $5 \mathrm{~m} / \mathrm{s}$, and then

255 placed on ice. Samples were then centrifuged for 3 minutes at $17,000 \mathrm{~g}$ and $4^{\circ} \mathrm{C} .300 \mu \mathrm{L}$ of

256 supernatant was then removed and subjected to the same chemagic extraction as used on the

257 liquid samples. RNA extracts were stored at $-80^{\circ} \mathrm{C}$ for 10 days and then transferred to $-20^{\circ} \mathrm{C}$ for 258 two days until quantification.

\subsection{Quantification}

2.6.1 Reverse Transcription - Droplet Digital Polymerase Chain Reaction (RT-ddPCR)

262 One step RT-ddPCR was conducted with One-Step RT-ddPCR Advanced Kit for Probes

263 (1864021, Bio-Rad) on the QX200 AutoDG Droplet Digital PCR System (Bio-Rad) to quantify

264 the concentration of N1 SARS-CoV-2, N2 SARS-CoV-2, and M BCoV gene targets in extracted 265 samples. Primer and probe information can be found in Table S1. Reaction mixes were prepared 266 on ice according to the composition outlined in Table S2 for N1 and N2, and Table S3 for 
medRxiv preprint doi: https://doi.org/10.1101/2020.11.27.20238980; this version posted November 30, 2020. The copyright holder for this preprint (which was not certified by peer review) is the author/funder, who has granted medRxiv a license to display the preprint in perpetuity.

It is made available under a CC-BY-NC-ND 4.0 International license .

267 BCoV. RNA template for $\mathrm{BCoV}$ was diluted 50x to attain a concentration within the

268 quantifiable range of the ddPCR equipment. Thermocycling conditions are outlined in Table S6.

269 After thermocycling, samples were held at $4^{\circ} \mathrm{C}$ for no longer than 12 hours until being read on

270 the QX200 Droplet Reader (18644003, Bio-Rad). Droplet data was analyzed on the QuantaSoft

271 v1.7.4 software. Manual thresholding of droplets was only performed when QuantaSoft was

272 unable to automatically threshold.

273 2.6.2 Reverse Transcription - Quantitative Polymerase Chain Reaction (RT-qPCR)

274 One step RT-qPCR was conducted with qPCRBIO Probe 1-Step Go Separate-ROX (PB25.44-

275 12, PCR Biosystems) on the QuantStudio 3 Real Time PCR System (A28567, Applied

276 Biosystems) to quantify the concentration of VGP pMMoV gene targets in extracted samples.

277 Primer and probe information can be found in Table S1. Reaction mixes were prepared on ice

278 according to the composition outlined in Table S4. RNA template for pMMoV was taken from

279 the 50x dilutions created for measuring $\mathrm{BCoV}$ to conserve undiluted extract. Thermocycling

280 conditions are outlined in Table S7. qPCR data was analyzed on the QuantStudio Design and

281 Analysis v1.4 software.

282

283 Standards of linear DNA (IDT), $708 \mathrm{bp}$ in length, were prepared and ran in triplicate in a dilution

284 series with concentrations at $0.69,6.9,69,690,6,900,69,000$, to 690,000 gene copies/ $\mu \mathrm{L}$

285 standard. Herring sperm DNA (D1811, Promega) at a final concentration of $10 \mathrm{ng} / \mu \mathrm{L}$ was used

286 to dilute the standards as a carrier DNA to preserve pMMoV standard DNA fragments during

287 freeze-thaws. 
medRxiv preprint doi: https://doi.org/10.1101/2020.11.27.20238980; this version posted November 30, 2020. The copyright holder for this preprint (which was not certified by peer review) is the author/funder, who has granted medRxiv a license to display the preprint in perpetuity.

It is made available under a CC-BY-NC-ND 4.0 International license .

The LoQ for ddPCR was defined as 3 positive droplets per 10,000 total droplets generated by the

290 instrument as recommended by the manufacturer. The volume of an individual droplet $(0.86 \mathrm{~nL})$

291 was then used to calculate a LoQ of 0.767 gene copies/ $\mu \mathrm{L}$ RNA template for a reaction setup

292 with $10 \mu \mathrm{L}$ of RNA template.

294 The LoQ for RT-qPCR was determined to be 0.69 gene copies/ $\mu \mathrm{L}$ RNA template for a reaction 295 setup with $4 \mu \mathrm{L}$ of RNA template. This was the concentration of the lowest standard used in our 296 calibration curve. pMMoV was the only gene target measured through RT-qPCR, and all values

297 were significantly above this limit. Concentration factors (Table S8-S13), average percent

298 recovery, and unit conversions were then used to convert this raw LoQ to an effective LoQ

299 associated with each concentration method (Eqn. 1).

$$
\text { Equation 1: } L o Q_{\text {eff }}=\frac{L o Q_{\text {method }}}{\% \text { Recovery } B C o V}=\frac{L o Q_{\text {raw }}}{\% \text { Recovery BCoV * Concentration Factor }}
$$

300 Measurements below the LoQ may indicate presence of gene targets but are not reliably accurate 301 measurements of the concentration.

\section{Results \& Discussion}

305 We first evaluated the effectiveness of five concentration methods at detecting and quantifying

306 the SARS-CoV-2 RNA in wastewater samples. We obtained 24 hour composite wastewater

307 samples from six different WWTPs in Houston covering a range of influent flow rates, 
medRxiv preprint doi: https://doi.org/10.1101/2020.11.27.20238980; this version posted November 30, 2020. The copyright holder for this preprint (which was not certified by peer review) is the author/funder, who has granted medRxiv a license to display the preprint in perpetuity.

It is made available under a CC-BY-NC-ND 4.0 International license .

308

309

310

311

312

313

314

315

316

317

318

319

320

321

322

323

324

325

326

327

328

329

330

population sizes, and wastewater compositions (Table 1). We also created a negative control

sample that contains only DI water that had been spiked with the BCoV surrogate. We applied

each of the five different concentration methods to each sample in triplicate, extracted the RNA

of the SARS-CoV-2 virus, and quantified the concentration of CDC target N1 and N2 using

digital droplet PCR (ddPCR). We then back calculated the concentration of the virus in terms of

copies of the virus per liter of wastewater (Figure 2A, B).

The concentration methods use different mechanisms to concentrate SARS-CoV-2. HA filtration

concentrates via manipulation of charge interactions between virus particles and filter media

(Cashdollar and Wymer, 2013). The addition of salts effectively replaces the repulsive

interactions between the negatively charged virus surface and the negatively charged surface of

the filter with positive-ion bridges. The bead beating method then desorbs and ruptures virus

particles absorbed to the filter membrane surface. In the HA filtration with elution method, an

eluent is added that desorbs the virus particles from the filter membrane surface into a smaller

volume by altering the $\mathrm{pH}$. The PEG method concentrates by precipitation of virus particles upon

addition of polyethylene glycol and sodium chloride. Although there is uncertainty in the exact

mechanism, virus precipitation is believed to occur similarly to precipitation of proteins by PEG,

where water molecules are drawn from the solution to hydrate PEG molecules, thereby

increasing the effective protein concentration, making it insoluble, enabling the proteins to

precipitate after reaching saturation (Ingham, 1990; Yamamoto et al., 1970). Ultrafiltration

concentrates via size exclusion, allowing water and other small particles to pass through a filter,

but blocking larger sized particles like SARS-CoV-2 virus (Cashdollar and Wymer, 2013). The

different mechanisms involved in these concentration methods lead to different degrees of

recovery of SARS-CoV-2, BCoV, and pMMoV. 
medRxiv preprint doi: https://doi.org/10.1101/2020.11.27.20238980; this version posted November 30, 2020. The copyright holder for this preprint (which was not certified by peer review) is the author/funder, who has granted medRxiv a license to display the preprint in perpetuity.

It is made available under a CC-BY-NC-ND 4.0 International license .

331 All five of the tested concentration methods were able to detect the presence of SARS-CoV-2

332 RNA, but varied significantly in viral RNA titer. Direct extraction yielded the highest apparent

333 concentration of SARS-CoV-2 RNA across all wastewater samples. In contrast, PEG had

334 consistently lower signal for SARS-CoV-2 RNA. Both methods involving HA filtration (with

335 bead beating and with elution) yielded similar concentrations that were about a half log lower

336 than direct extraction. In all cases, the resulting concentration of N1 and N2 per liter of

337 wastewater was highly dependent on the concentration method used, more so than from which

338 WWTP the sample came from. This suggests that the true concentration of SARS-CoV-2 RNA

339 from all six WWTPs was roughly the same. It is worth noting that these measurement systems

340 may be detecting free SARS-CoV-2 RNA along with intact SARS-CoV-2 virus particles, and

341 that each concentration method may have a different ability to measure that free SARS-CoV-2

342 RNA.

343 Direct extraction yielded the highest concentrations of genome copies per $\mathrm{L}$ of wastewater due to

344 the fewest losses associated with concentration and the largest concentration factor applied.

345 When the results are shown in terms of the raw data, copies of N1 or N2 per $\mu \mathrm{L}$ of RNA

346 template, direct extraction had the lowest raw concentrations of viral RNA and many data points

347 were below the LoQ (as shown by the line in (Figure 2C, D). Furthermore, the only method that

348 yielded results that were consistently above the LoQ for all WWTPs and both targets was HA

349 filtration with bead beating. Because the LoQ is constant in terms of copies of RNA per $\mu \mathrm{L}$ of

350 RNA template, the method that yields the highest raw concentration of RNA per $\mu \mathrm{L}$ of template

351 is the one that produces quantifiable signal. Therefore, when evaluating concentration methods, a

352 key metric for consideration is not the genome copies per liter wastewater, but the copies per $\mu \mathrm{L}$

353 of RNA template. In the set of methods we evaluated, we found that HA filtration with bead 
medRxiv preprint doi: https://doi.org/10.1101/2020.11.27.20238980; this version posted November 30, 2020. The copyright holder for this preprint (which was not certified by peer review) is the author/funder, who has granted medRxiv a license to display the preprint in perpetuity.

It is made available under a CC-BY-NC-ND 4.0 International license .

354 beating performed the best in terms of having the highest raw genome copies per microliter of

355 RNA template and was thus consistently able to quantify SARS-CoV-2 RNA in all wastewater

356 samples tested.

357 One important decision in SARS-CoV-2 RNA concentration that may impact sensitivity,

358 reproducibility, and variability is the volume of input wastewater. As input volume increases you

359 are left with a higher concentration of virus RNA in a concentrate of the same volume.

360 However, this does not come without sacrifice. In all three filtration-based methods, there is a

361 nearly exponential relationship between input volume and processing time (data not shown),

362 which can be an issue for the logistics of WBE for SARS-CoV-2. There is also an upper limit on

363 filterable volume, as pores in the filter membrane become completely blocked. In the case of

364 PEG, larger input volume means larger volumes need to be placed in centrifuges which have

365 maximum volumetric capacities and increases in startup price associated with increasing that

366 capacity by purchasing higher-powered centrifuges. Additionally, the fraction of recovered virus

367 may not stay constant for all methods with a higher volume. In the case of HA filtration

368 methods, for example, absorption sites on the filter surface may be increasingly occupied as

369 additional volume is filtered, reducing the amount of virus particles and virus RNA that can

370 absorb to the surface. All concentration methods in this study, except for direct extraction and

371 HA filtration with elution, used $50 \mathrm{~mL}$ of input volume. Direct extraction used $300 \mu \mathrm{L}$ due to

372 volume limits of the extraction kit that we used, and HA filtration with elution used $25 \mathrm{~mL}$ due

373 to rate of filtration limits in the operating lab. An in-depth investigation into volume

374 optimization was out of the scope of this study but could be performed to improve the sensitivity

375 and reduce the variability of each of the concentration methods. 
medRxiv preprint doi: https://doi.org/10.1101/2020.11.27.20238980; this version posted November 30, 2020. The copyright holder for this preprint (which was not certified by peer review) is the author/funder, who has granted medRxiv a license to display the preprint in perpetuity.

It is made available under a CC-BY-NC-ND 4.0 International license.

\begin{tabular}{|c|c|c|c|c|c|c|c|}
\hline Method & 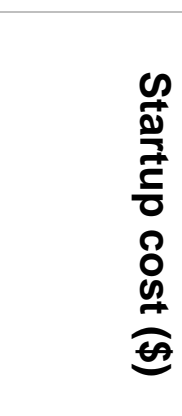 & 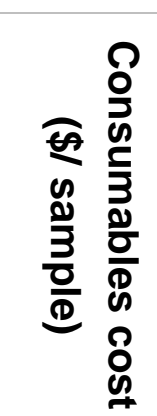 & 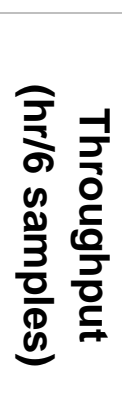 & 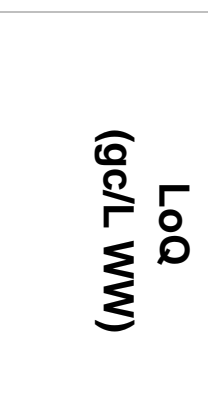 & 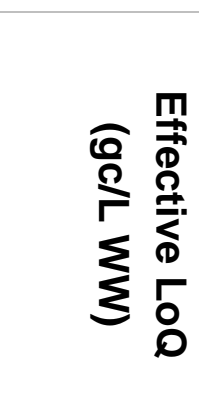 & $\begin{array}{l}\text { 罗 } \\
\stackrel{2}{<} \\
\stackrel{\circ}{\circ}\end{array}$ & $\begin{array}{l}\text { o } \\
\stackrel{3}{3} \\
\stackrel{0}{<} \\
\stackrel{0}{\circ}\end{array}$ \\
\hline $\begin{array}{c}\text { Direct } \\
\text { extraction }\end{array}$ & $\$ 5,650$ & $\$ 0.14$ & 0.1 & $2.56 \mathrm{E}+05$ & $8.39 E+06$ & 14.6 & 29.9 \\
\hline $\begin{array}{l}\text { HA Filtration + } \\
\text { Bead Beating }\end{array}$ & $\$ 15,368$ & $\$ 1.50$ & 0.7 & $3.07 E+03$ & $2.76 \mathrm{E}+05$ & 27.3 & 25.9 \\
\hline $\begin{array}{l}\text { HA Filtration + } \\
\text { Elution }\end{array}$ & $\$ 11,160$ & $\$ 5.80$ & 0.5 & $2.56 \mathrm{E}+04$ & $3.89 \mathrm{E}+06$ & 20.9 & 31.8 \\
\hline PEG & $\$ 20,288$ & $\$ 11.02$ & 4.6 & $2.56 \mathrm{E}+03$ & $2.70 \mathrm{E}+06$ & 39.0 & 49.8 \\
\hline Ultrafiltration & $\$ 9,000$ & $\$ 12.10$ & 1.5 & $7.67 \mathrm{E}+03$ & $2.63 E+06$ & 24.4 & 49.5 \\
\hline
\end{tabular}

377 Table 2: Summary of key metrics of each concentration method. A detailed breakdown of costs

378 and list of equipment used can be found in S14-23.

380 Next, we compared characteristics related to the practicality of the different concentration

381 methods. We did this comparison to help relevant parties decide which SARS-CoV-2 RNA

382 concentration method is best suited for their situation. Laboratories might have differences in

383 availability of resources (equipment, labor) and in the number of samples requiring analysis, and

384 thus can use these results to optimize workflow.

385

386 The startup costs reflect equipment that was unique to each concentration method. Standard lab

387 equipment required by all concentration methods, such as pipettes and PPE, were not included in 
medRxiv preprint doi: https://doi.org/10.1101/2020.11.27.20238980; this version posted November 30, 2020. The copyright holder for this preprint (which was not certified by peer review) is the author/funder, who has granted medRxiv a license to display the preprint in perpetuity.

It is made available under a CC-BY-NC-ND 4.0 International license .

388

389

390

391

392

393

394

395

396

397

398

399

400

401

402

403

404

405

406

407

408

409

410

these calculations. Additionally, RNA extraction costs were not included, except in the case for

the price of a bead beater, which is necessary to quantify RNA when using the HA filtration with

bead beating method. The largest factor contributing to startup costs in all cases was centrifuges.

The differences in startup costs was generally due to differences in cost of the specific centrifuge

required. A centrifuge is not necessary to perform the HA filtration with bead beating method,

but centrifuging samples prior to concentration to remove solids drastically decreased filtering

time and thus greatly increased throughput efficiency (data not shown). Pecson et al. also found

that a solids removal step did not show a clear impact on the quantification results of SARS-

CoV-2 (Pecson et al., 2020). A detailed breakdown of startup costs can be found in Table S14-

S18.

By far the most expensive method in terms of consumables cost per sample is ultrafiltration. The Amicon® filters required by this process are expensive and not reusable. The PEG method is also relatively high in cost for a similar reason; the unique bottom top filters are costly and cannot be reused. It may be possible to lower costs for PEG by purchasing individual $0.22 \mu \mathrm{m}$ filters to use in a filter manifold setup, however, this would further sacrifice throughput, as time would be required to rinse the manifold setup to prevent cross contamination. HA filtration with bead beating and elution methods had comparable consumables costs, although the elution method is more expensive due to the use of an EZ-Fit ${ }^{\mathrm{TM}}$ Filtration Unit. We do not suggest reusing or replacing the EZ-Fit units to lower cost, since contact with the flipped filter and underlying surface poses a large cross contamination risk if done in a repeatedly used filter manifold. Direct extraction was the least expensive method since specialized consumables were not required. A detailed breakdown of consumable costs can be found in Table S19-S23. 
medRxiv preprint doi: https://doi.org/10.1101/2020.11.27.20238980; this version posted November 30, 2020. The copyright holder for this preprint (which was not certified by peer review) is the author/funder, who has granted medRxiv a license to display the preprint in perpetuity.

It is made available under a CC-BY-NC-ND 4.0 International license .

412 Throughput time was also assessed as different groups conducting WBE for SARS-CoV-2 have

413 varying numbers of samples and unique requirements for turnaround times needed to report data.

414 All concentration methods included a centrifugation step to remove solids in their throughput

415 time. The PEG method had the lowest throughput, largely because of the precipitation step,

416 taking at least 3 hours longer to process a batch of samples than the other methods evaluated. In

417 our study, PEG was precipitated overnight to lower the burden on lab workers, but our

418 experience with PEG concentration suggests that this time could be lowered to 4 hours without

419 lowering recovery. Other literature concentrating viruses using PEG have reduced precipitation

420 time further, but investigation of the effect of this on recovery was out of the scope of this study.

421 Ultrafiltration had the second lowest throughput due to non-filterable matter accumulation during

422 centrifugation. In centrifugation steps that allow fluid to pass directly through a filter, clogging

423 and precipitation is probable, thus increasing processing time. Direct extraction had the highest

424 throughput efficiency, since it only required a five minute solids removal step. HA filtration with

425 bead beating and HA filtration with elution had high and comparable throughputs. A detailed

426 breakdown of throughput can be found in Table $\mathbf{S 2 4}$.

427

428 We then determined the LoQ for all of the concentration methods. Here we defined the LoQ by

429 translating the minimum droplet counts required to reliably quantify gene targets (an approach

430 recommended by Bio-Rad). The minimum droplet count, 3 positive droplets per 10,000 total

431 droplets, translates to 0.767 gene copies/ $\mu \mathrm{L}$ ddPCR reaction. The amount of RNA template and

432 different concentration factors between methods were then used to calculate the LoQ in Table 2.

433 PEG had the highest concentration factor of 300, leading to the lowest LoQ, while direct 
medRxiv preprint doi: https://doi.org/10.1101/2020.11.27.20238980; this version posted November 30, 2020. The copyright holder for this preprint (which was not certified by peer review) is the author/funder, who has granted medRxiv a license to display the preprint in perpetuity.

It is made available under a CC-BY-NC-ND 4.0 International license .

434 extraction has the highest LoQ because there was no concentration occurring. It is important to

435 note that this LoQ does not take into account losses incurred by the different concentration

436 methods. The optimal method will balance a low LoQ with a high recovery leading to raw

437 concentrations of gene targets being significantly above the raw LoQ. We accounted for recovery

438 by averaging percent recovery of $\mathrm{BCoV}$ for the different methods and incorporating that average

439 into an effective LoQ. It should be noted that $\mathrm{BCoV}$ has yet to be identified as an optimal

440 surrogate for SARS-CoV-2 but can still provide valuable information in this context. The

441 recovery of $\mathrm{BCoV}$ through PEG, averaging $0.09 \%$, was low enough to increase the effective

442 LoQ to higher than that of HA filtration with bead beating. When incorporating percent recovery

443 of the different methods, HA filtration with bead beating had the lowest effective LoQ at 2.76e5

444 gene copies/L wastewater, and was almost an order of magnitude lower (more sensitive) than the

445 other concentration methods [Table 2]. The effective LoQ is directly related to the sensitivity of

446 the concentration method, which is a critical factor in being able to reliably quantify SARS-CoV-

4472 in wastewater samples, especially when there is relatively low community prevalence.

448 Lowering the effective LoQ relative to direct extraction is the essential reason why we include a

449 concentration step, because it makes lower concentrations of virus more reliably quantifiable.

451 In a study that investigated different overall processing methods for measurement of SARS-

$452 \mathrm{CoV}-2$, no systematic impact by the concentration method was found for results corrected with a

453 process control (Pecson et al., 2020). As mentioned previously however, there were

454 confounding factors, such as differences in extraction and quantification steps, between the

455 different processing methods that could have skewed the comparison of the concentration step.

456 Another study investigated the recovery of murine hepatitis virus (MHV), a proposed process 
medRxiv preprint doi: https://doi.org/10.1101/2020.11.27.20238980; this version posted November 30, 2020. The copyright holder for this preprint (which was not certified by peer review) is the author/funder, who has granted medRxiv a license to display the preprint in perpetuity.

It is made available under a CC-BY-NC-ND 4.0 International license .

457 control for SARS-CoV-2, between multiple concentration methods with the same extraction and

458 quantification steps (Ahmed et al., 2020b). The general ranking of the recovery results for the

459 concentration methods they tested generally agree with ours in the order of best to worst: HA

460 filtration with bead beating, ultrafiltration, and PEG. A third study compared concentration of

461 MHV via PEG, ultracentrifugation, and ultrafiltration and found that ultrafiltration was the

462 preferrable concentration method for enveloped viruses of those three methods, but this study

463 based its results on the quantification of live virus and not virus RNA (Ye et al., 2016). They

464 suggest that PEG is a preferred method only for non-enveloped viruses. Overall, our study our

465 study controlled for different confounding factors and directly measured SARS-CoV-2 RNA,

466 unlike these previous two studies.

\subsection{Recovery of corrective surrogates}

468 In addition to SARS-CoV-2 RNA, we compared the concentrations of BCoV and pMMoV RNA

469 in the WWTP samples processed via the different concentration methods. Each wastewater

470 sample was immediately spiked with a known concentration of $\mathrm{BCoV}$ upon reception at the

471 collection site. Samples that had passed through concentration and extraction protocols were then

472 analyzed through ddPCR $(\mathrm{BCoV})$ and $\mathrm{qPCR}(\mathrm{pMMoV})$ to determine their concentrations in the

473 wastewater samples.

\section{$474 \quad 3.4$ Bovine Coronavirus (BCoV) Process Control}

475 A process control is necessary when exact RNA recovery efficiency of the target component

476 across different processing steps is unknown, or when determining these recoveries may be

477 impractical. By spiking in a known concentration of the process control at the beginning of the

478 process or at different stages throughout the process and comparing the measured concentration 
medRxiv preprint doi: https://doi.org/10.1101/2020.11.27.20238980; this version posted November 30, 2020. The copyright holder for this preprint (which was not certified by peer review) is the author/funder, who has granted medRxiv a license to display the preprint in perpetuity.

It is made available under a CC-BY-NC-ND 4.0 International license .

479 to the expected concentration, it is possible to determine the overall recovery of the process

480 control and loss of the process control during sample processing. If the process control has been

481 validated, and is known to behave in a way similar to the target component, then these losses can

482 be incorporated into the measured concentration of the target component to estimate a "true"

483 measure of the target component in the sample. Process controls can also be used simply as

484 positive controls to ensure that nothing went awry during sample processing and analysis.

Recent SARS-CoV-2 WBE studies have used a variety of process controls, including MHV

487 (Ahmed et al., 2020b), transmissible gastroenteritis virus (TGEV) (Mlejnkova et al., 2020),

488 human coronavirus (HCoV 229E) (La Rosa et al., 2021), Phi 6 (Sherchan et al., 2020), bovine

489 respiratory syncytial virus (BRSV) (Gonzalez et al., 2020), and BCoV (Gonzalez et al., 2020).

490 However, no single process control has proven, as of yet, to be significantly more indicative of

491 SARS-CoV-2 recovery than other process controls. In this work we sought to assess BCoV as a

492 process control by comparing its recovery across different methods and wastewater samples

493 against the yields of SARS-CoV-2 RNA.

494

495 We chose BCoV because of its similarity to SARS-CoV-2, as both viruses are part of the genus

496 Betacoronaviridae. SARS-CoV-2 is an enveloped virus, generally spherical in shape with mild

497 pleomorphism (60-140 nm diameter) and a $29.9 \mathrm{~kb}$ length genome (Zhu et al., 2020). BCoV is a

498 pleomorphic (65-210 nm diameter), enveloped RNA virus with a 27 - 32 kb length genome (Saif,

499 2010). Both BCoV and SARS-CoV-2 carry a spike (S) glycoprotein on their envelope surface,

500 while only $\mathrm{BCoV}$ carries an additional, large protein on its envelope surface known as

501 hemagglutinin-esterase (HE) glycoprotein (Saif, 2010). Apart from structural similarity, BCoV is 
medRxiv preprint doi: https://doi.org/10.1101/2020.11.27.20238980; this version posted November 30, 2020. The copyright holder for this preprint (which was not certified by peer review) is the author/funder, who has granted medRxiv a license to display the preprint in perpetuity.

It is made available under a CC-BY-NC-ND 4.0 International license .

502 also easily obtainable in an attenuated form from a common cattle vaccine and poses a low

503 health risk to humans.

504

505 The magnitude of recovery of BCoV reflected the magnitude of recovery of N1 and N2 across

506 concentration methods. Like N1 and N2, the highest to lowest recovery of BCoV from the

507 different concentration methods occurred in the order of direct extraction, HA filtration with

508 bead beating, HA filtration with elution, ultrafiltration, and finally PEG. Overall, this suggests

509 that BCoV could be a good surrogate for SARS-CoV-2 as relative recovery of BCoV across

510 concentration methods mirrors the relative recoveries of SARS-CoV-2. However, there is some

511 difficulty in directly comparing recovery of N1 and N2 to BCoV due to the number of N1 and

$512 \mathrm{~N} 2$ measurements that were below the LoQ for ddPCR. Additionally, it is not clear what the

513 dominant forms (intact viral particle vs free RNA) of BCoV and SARS-CoV-2 are when they

514 reach the concentration step of the measurement process and how this affects concentration.

515 More research is needed to characterize the form of SARS-CoV-2 in wastewater and understand

516 how the form impacts concentration to inform the choice of an appropriate surrogate.

518 Interestingly, DI water controls spiked with BCoV showed significantly different levels of

519 recoveries compared to wastewater samples concentrated via the same method. One potential

520 explanation for this could be rupture of the viral particles due to a large difference in osmotic

521 pressures across viral capsid/envelope in DI water. Rupture may not occur in wastewater

522 samples due to a significant amount of dissolved compounds reducing differences in osmotic

523 pressure inside and outside of the viral particle. Thus, the disparate concentration methods may

524 have different effects on ruptured versus unruptured virus. 
medRxiv preprint doi: https://doi.org/10.1101/2020.11.27.20238980; this version posted November 30, 2020. The copyright holder for this preprint (which was not certified by peer review) is the author/funder, who has granted medRxiv a license to display the preprint in perpetuity.

It is made available under a CC-BY-NC-ND 4.0 International license .

526 There are many factors that affect wastewater concentration of SARS-CoV-2 RNA between

527 excretion in feces and quantification in the lab that potentially confound translation of

528 concentration to community prevalence. While a process control, like $\mathrm{BCoV}$, can be used to

529 account for factors during the measurement process (i.e. between sampling and quantification), a

530 normalization factor attempts to account for factors during the measurement process and

531 additional upstream factors, like dilution in the sewer system.

533 pMMoV has been suggested as a promising normalization factor for SARS-CoV-2 (Wu et al.,

534 2020). It is the most abundant RNA virus found in human feces due to its origin in peppers and

535 pepper containing products and has previously been proposed as a water quality and fecal

536 pollution indicator (Kitajima et al., 2018; Rosario et al., 2009). In theory, it is excreted in

537 relatively consistent amounts in humans across a population and will travel alongside SARS-

$538 \mathrm{CoV}-2$ viral particles and viral RNA in the conveyance system, experiencing the same

539 conditions. pMMoV is a rod-shaped ( $312 \mathrm{~nm}$ length), non-enveloped RNA virus with a $6.4 \mathrm{~kb}$

540 length genome in the Tobamovirus family (Kitajima et al., 2018). Due to a number of structural

541 differences between $\mathrm{pMMoV}$ and SARS-CoV-2, pMMoV is better used as a fecal indicator than

542 as a corrective process control.

544 Direct extraction showed the highest recovery of $\mathrm{pMMoV}$ in all the wastewater samples (Figure

545 3). Three other methods, HA filtration with bead beating, HA filtration with elution, and

546 ultrafiltration showed roughly equivalent recoveries of pMMoV. The PEG method had the 
medRxiv preprint doi: https://doi.org/10.1101/2020.11.27.20238980; this version posted November 30, 2020. The copyright holder for this preprint (which was not certified by peer review) is the author/funder, who has granted medRxiv a license to display the preprint in perpetuity.

It is made available under a CC-BY-NC-ND 4.0 International license .

547 lowest recoveries of $\mathrm{pMMoV}$ of all the concentration methods. All of the resulting pMMoV

548 measurements, with the exception of two, were well above the LoQ.

549 The relative effectiveness of direct extraction and the PEG method compared to the other

550 concentration methods was about the same between measurement of pMMoV and measurement

551 of N1 and N2. However, while HA filtration with bead beating, HA filtration with elution, and

552 ultrafiltration were roughly equivalent for $\mathrm{pMMoV}$, HA filtration with bead beating recovered

553 the most N1 and N2 of the three respective concentration methods.

555 A number of differences between pMMoV and SARS-CoV-2 may be the cause of these

556 differences. For example, it may be that the protein capsid and envelope of SARS-CoV-2 are

557 easier to rupture via bead beating than the sole protein capsid of pMMoV. Alternatively, it is

558 possible that the forms of the virus are different after conveyance in the sewers system. One of

559 the viruses may primarily exist in the form of free RNA due to decay of their envelope and/or

560 protein capsid, while the other virus may be largely intact. It is currently not clear what form

561 either pMMoV or SARS-CoV-2 are in when they reach the concentration step, how these forms

562 impact concentration, or how different characteristics of the two viruses impact concentration,

563 but they are areas that should be explored further.

5643.6 Variability of measurement between concentration methods with BCoV and pMMoV

565 The variability of measurements between each concentration method was determined using the

566 coefficient of variance (CV) for $\mathrm{BCoV}$ and pMMoV (Table 2). The lower the CV, the lower the

567 variability and the higher confidence one can have in a measured value. Further, if CV is low

568 enough, it may be reasonable to reduce replicates (i.e. from triplicates to duplicates) to save on

569 cost and throughput. The CV was measured for each WWTP for a particular method and then 
medRxiv preprint doi: https://doi.org/10.1101/2020.11.27.20238980; this version posted November 30, 2020. The copyright holder for this preprint (which was not certified by peer review) is the author/funder, who has granted medRxiv a license to display the preprint in perpetuity.

It is made available under a CC-BY-NC-ND 4.0 International license.

570 averaged for all WWTPs in the method to get the CV of the whole method. The PEG method

571 showed the highest average CV, while the HA filtration with bead beating method had a

572 generally low $\mathrm{CV}$ for both $\mathrm{BCoV}$ and $\mathrm{pMMoV}$. As of now, it is not clear what causes the

573 difference in variability between each concentration method. We chose not to directly

574 incorporate CV of N1 and N2 gene targets because a large proportion of measurements were

575 below the LoQ. Therefore variability in N1 and N2 would be more attributed to the

576 quantification procedure that was used to establish the LoQ as opposed to variability caused by

577 the particular concentration method. Between BCoV and pMMoV, the BCoV CV is likely a

578 better indicator of a potential SARS-CoV-2 CV due to BCoVs higher structural similarity to

579 SARS-CoV-2 than pMMoV.

581 4. Conclusion

582 By directly measuring N1, N2, BCoV, and pMMoV, we assessed the recovery and practicality of

583 different concentration methods required for SARS-CoV-2 WBE. HA filtration with bead

584 beating showed high recovery of all gene targets at a significant distance above the LoQ, leading

585 to low variability across measurements. The same method also demonstrated relatively moderate

586 startup costs, low cost per sample, and high throughput. HA filtration with bead beating is

587 therefore a preferred concentration method in many situations from the perspective of recovery

588 and practicality. Additional attention should be paid optimizing the sensitivity and recovery of all

589 concentration methods. Future work should also identify the form of SARS-CoV-2 RNA and

590 establish how this affects measurements via the different concentration methods. Additionally,

591 more work needs to be done to determine the best process controls and normalization factors for

592 SARS-CoV-2. The WBE for SARS-CoV-2 community needs to identify process controls and 
medRxiv preprint doi: https://doi.org/10.1101/2020.11.27.20238980; this version posted November 30, 2020. The copyright holder for this preprint (which was not certified by peer review) is the author/funder, who has granted medRxiv a license to display the preprint in perpetuity.

It is made available under a CC-BY-NC-ND 4.0 International license .

593 surrogates that behave similarly to SARS-CoV-2 in wastewater and Overall, this work further

594 demonstrates that methods to concentrate SARS-CoV-2 RNA for WBE are low cost and reliable.

595

596 Acknowledgements

597 We thank Kathy Ensor for her invaluable contributions to the implementation of a wastewater

598 monitoring system in Houston. We thank Paul Zappi, Rae Mills, Carol LaBreche, Walid

599 Samarneh, and Aisha Niang from Houston Water for their assistance in collecting wastewater

600 samples. We thank Lilian Mojica, Braulio Garcia, Courtney Hundley, Jeremy Rangel, Kelsey

601 Caton, Rebeca Schneider, Daniel Bahrt, Kaavya Damakonda, Patrick Key, and Naomi Macias

602 from the Houston Health Department for their assistance in sample collection and data analysis.

603 We thank Kristina Cibor, Esther Lou, Basmah Maiga, Camille McCall, and Pavan Raja, and for

604 their assistance in sample collection, processing, analysis, and project management. We thank

605 Jeseth Delgado Vela, Adam Smith, Nadine Kotlarz, Francis de los Reyes, and Angela Harris for

606 their discussions on wastewater-based epidemiology.

607

608 Funding

609 This work was supported by the Houston Health Department, grants from the National Science

610 Foundation (CBET 2029025), and Rice University. P.K. was funded by a Johnson \& Johnson

611 WiSTEM2D award. Z.W.L. was funded by an Environmental Research \& Education Foundation

612 scholarship and Rice University. P.A. was funded by a National Science Foundation award

613 (CBET 1932000). T.C. was funded by the National Academies of Science, Engineering, and

614 Medicine Gulf Research Early Career Research Fellowship. 
medRxiv preprint doi: https://doi.org/10.1101/2020.11.27.20238980; this version posted November 30, 2020. The copyright holder for this preprint (which was not certified by peer review) is the author/funder, who has granted medRxiv a license to display the preprint in perpetuity.

It is made available under a CC-BY-NC-ND 4.0 International license.

615

616

617

618

619

620

621

622

623

624

625

626

627

628

629

630

631

632

633

634

635

636

\section{Bibliography}

Ahmed, W., Angel, N., Edson, J., Bibby, K., Bivins, A., O’Brien, J.W., Choi, P.M., Kitajima, M., Simpson, S.L., Li, J., Tscharke, B., Verhagen, R., Smith, W.J.M., Zaugg, J., Dierens, L., Hugenholtz, P., Thomas, K.V., Mueller, J.F., 2020a. First confirmed detection of SARS-CoV-2 in untreated wastewater in Australia: A proof of concept for the wastewater surveillance of COVID-19 in the community. Sci. Total Environ. 138764. https://doi.org/10/ggs449

Ahmed, W., Bertsch, P.M., Bivins, A., Bibby, K., Farkas, K., Gathercole, A., Haramoto, E., Gyawali, P., Korajkic, A., McMinn, B.R., Mueller, J.F., Simpson, S.L., Smith, W.J.M., Symonds, E.M., Thomas, K.V., Verhagen, R., Kitajima, M., 2020b. Comparison of virus concentration methods for the RT-qPCR-based recovery of murine hepatitis virus, a surrogate for SARS-CoV-2 from untreated wastewater. Sci. Total Environ. 739, 139960. https://doi.org/10.1016/j.scitotenv.2020.139960

Cashdollar, J.L., Wymer, L., 2013. Methods for primary concentration of viruses from water samples: a review and meta-analysis of recent studies. J. Appl. Microbiol. 115, 1-11. https://doi.org/10.1111/jam.12143

Cheung, K.S., Hung, I.F.N., Chan, P.P.Y., Lung, K.C., Tso, E., Liu, R., Ng, Y.Y., Chu, M.Y., Chung, T.W.H., Tam, A.R., Yip, C.C.Y., Leung, K.-H., Fung, A.Y.-F., Zhang, R.R., Lin, Y., Cheng, H.M., Zhang, A.J.X., To, K.K.W., Chan, K.-H., Yuen, K.-Y., Leung, W.K., 2020. Gastrointestinal Manifestations of SARS-CoV-2 Infection and Virus Load in Fecal Samples From a Hong Kong Cohort: Systematic Review and Meta-analysis. Gastroenterology 159, 81-95. https://doi.org/10/ggrqjr 
medRxiv preprint doi: https://doi.org/10.1101/2020.11.27.20238980; this version posted November 30, 2020. The copyright holder for this preprint (which was not certified by peer review) is the author/funder, who has granted medRxiv a license to display the preprint in perpetuity.

It is made available under a CC-BY-NC-ND 4.0 International license .

637 Colosi, L.M., Barry, K.E., Kotay, S.M., Porter, M.D., Poulter, M.D., Ratliff, C., Simmons, W.,

638 Steinberg, L.I., Wilson, D.D., Morse, R., Zmick, P., Mathers, A.J., 2020. Development of

639 wastewater pooled surveillance of SARS-CoV-2 from congregate living settings.

640 medRxiv 2020.10.10.20210484. https://doi.org/10/ghjmm8

641 Crits-Christoph, A., Kantor, R.S., Olm, M.R., Whitney, O.N., Al-Shayeb, B., Lou, Y.C.,

642 Flamholz, A., Kennedy, L.C., Greenwald, H., Hinkle, A., Hetzel, J., Spitzer, S., Koble, J.,

643 Tan, A., Hyde, F., Schroth, G., Kuersten, S., Banfield, J.F., Nelson, K.L., 2020. Genome

644 sequencing of sewage detects regionally prevalent SARS-CoV-2 variants. medRxiv

$645 \quad 2020.09 .13 .20193805$. https://doi.org/10.1101/2020.09.13.20193805

646 Gonzalez, R., Curtis, K., Bivins, A., Bibby, K., Weir, M.H., Yetka, K., Thompson, H., Keeling,

647 D., Mitchell, J., Gonzalez, D., 2020. COVID-19 surveillance in Southeastern Virginia

648 using wastewater-based epidemiology. Water Res. 186, 116296.

649 https://doi.org/10.1016/j.watres.2020.116296

650 Hart, O.E., Halden, R.U., 2020. Computational analysis of SARS-CoV-2/COVID-19

651 surveillance by wastewater-based epidemiology locally and globally: Feasibility,

652 economy, opportunities and challenges. Sci. Total Environ. 730, 138875.

653 https://doi.org/10/ds22

654 Hellmér, M., Paxéus, N., Magnius, L., Enache, L., Arnholm, B., Johansson, A., Bergström, T., 655 Norder, H., 2014. Detection of Pathogenic Viruses in Sewage Provided Early Warnings 656 of Hepatitis A Virus and Norovirus Outbreaks. Appl. Environ. Microbiol. 80, 6771-6781.

657 https://doi.org/10/f245jt 
medRxiv preprint doi: https://doi.org/10.1101/2020.11.27.20238980; this version posted November 30, 2020. The copyright holder for this preprint (which was not certified by peer review) is the author/funder, who has granted medRxiv a license to display the preprint in perpetuity.

It is made available under a CC-BY-NC-ND 4.0 International license .

658

659

660

661

662

663

664

665

666

667

668

669

670

671

672

673

674

675

676

677

678

679

680

Ingham, K.C., 1990. [23] Precipitation of proteins with polyethylene glycol, in: Deutscher, M.P. (Ed.), Methods in Enzymology, Guide to Protein Purification. Academic Press, pp. 301306. https://doi.org/10.1016/0076-6879(90)82025-W

Kamel, A.H., Ali, M.A., El-Nady, H.G., Deraz, A., Aho, S., Pothier, P., Belliot, G., 2011. Presence of enteric hepatitis viruses in the sewage and population of Greater Cairo. Clin. Microbiol. Infect. 17, 1182-1185. https://doi.org/10.1111/j.1469-0691.2011.03461.x

Katayama, H., Haramoto, E., Oguma, K., Yamashita, H., Tajima, A., Nakajima, H., Ohgaki, S., 2008. One-year monthly quantitative survey of noroviruses, enteroviruses, and adenoviruses in wastewater collected from six plants in Japan. Water Res. 42, 14411448. https://doi.org/10.1016/j.watres.2007.10.029

Kitajima, M., Sassi, H.P., Torrey, J.R., 2018. Pepper mild mottle virus as a water quality indicator. Npj Clean Water 1, 1-9. https://doi.org/10/ghdbbx

La Rosa, G., Bonadonna, L., Lucentini, L., Kenmoe, S., Suffredini, E., 2020. Coronavirus in water environments: Occurrence, persistence and concentration methods - A scoping review. Water Res. 179, 115899. https://doi.org/10.1016/j.watres.2020.115899

La Rosa, G., Mancini, P., Bonanno Ferraro, G., Veneri, C., Iaconelli, M., Bonadonna, L., Lucentini, L., Suffredini, E., 2021. SARS-CoV-2 has been circulating in northern Italy since December 2019: Evidence from environmental monitoring. Sci. Total Environ. 750, 141711. https://doi.org/10.1016/j.scitotenv.2020.141711

Lago, P.M., Gary, H.E., Pérez, L.S., Cáceres, V., Olivera, J.B., Puentes, R.P., Corredor, M.B., Jímenez, P., Pallansch, M.A., Cruz, R.G., 2003. Poliovirus detection in wastewater and stools following an immunization campaign in Havana, Cuba. Int. J. Epidemiol. 32, 772777. https://doi.org/10/dfkdb3 
medRxiv preprint doi: https://doi.org/10.1101/2020.11.27.20238980; this version posted November 30, 2020. The copyright holder for this preprint (which was not certified by peer review) is the author/funder, who has granted medRxiv a license to display the preprint in perpetuity.

It is made available under a CC-BY-NC-ND 4.0 International license .

681 McCall, C., Wu, H., Miyani, B., Xagoraraki, I., 2020. Identification of multiple potential viral

682

683

684

685

686

687

688

689

690

691

692

693

694

695

696

697

698

699

700

701

702

diseases in a large urban center using wastewater surveillance. Water Res. 184, 116160. https://doi.org/10.1016/j.watres.2020.116160

Mesoraca, A., Margiotti, K., Viola, A., Cima, A., Sparacino, D., Giorlandino, C., 2020. Evaluation of SARS-CoV-2 viral RNA in fecal samples. Virol. J. 17, 86. https://doi.org/10.1186/s12985-020-01359-1

Mlejnkova, H., Sovova, K., Vasickova, P., Ocenaskova, V., Jasikova, L., Juranova, E., 2020. Preliminary Study of Sars-Cov-2 Occurrence in Wastewater in the Czech Republic. Int. J. Environ. Res. Public. Health 17, 5508. https://doi.org/10.3390/ijerph17155508

Pecson, B.M., Darby, E., Haas, C.N., Amha, Y., Bartolo, M., Danielson, R., Dearborn, Y., Giovanni, G.D., Ferguson, C., Fevig, S., Gaddis, E., Gray, D., Lukasik, G., Mull, B., Olivas, L., Olivieri, A., Qu, Y., Consortium, S.-C.-2 I., 2020. Reproducibility and sensitivity of 36 methods to quantify the SARS-CoV-2 genetic signal in raw wastewater: findings from an interlaboratory methods evaluation in the U.S. medRxiv 2020.11.02.20221622. https://doi.org/10.1101/2020.11.02.20221622

Prado, T., Fumian, T.M., Mannarino, C.F., Maranhão, A.G., Siqueira, M.M., Miagostovich, M.P., 2020. Preliminary results of SARS-CoV-2 detection in sewerage system in Niterói municipality, Rio de Janeiro, Brazil. Mem. Inst. Oswaldo Cruz 115. https://doi.org/10.1590/0074-02760200196

Rosario, K., Symonds, E.M., Sinigalliano, C., Stewart, J., Breitbart, M., 2009. Pepper Mild Mottle Virus as an Indicator of Fecal Pollution. Appl. Environ. Microbiol. 75, 72617267. https://doi.org/10/cvdh3j 
Saif, L.J., 2010. Bovine Respiratory Coronavirus. Vet. Clin. North Am. Food Anim. Pract. 26, 349-364. https://doi.org/10/drjdj9

Sherchan, S.P., Shahin, S., Ward, L.M., Tandukar, S., Aw, T.G., Schmitz, B., Ahmed, W., Kitajima, M., 2020. First detection of SARS-CoV-2 RNA in wastewater in North America: A study in Louisiana, USA. Sci. Total Environ. 743, 140621. https://doi.org/10.1016/j.scitotenv.2020.140621

709

710

Stadler, L.B., Ensor, K.B., Clark, J.R., Kalvapalle, P., LaTurner, Z.W., Mojica, L., Terwilliger, A., Zhuo, Y., Ali, P., Avadhanula, V., Bertolusso, R., Crosby, T., Hernandez, H., Hollstein, M., Weesner, K., Zong, D.M., Persse, D., Piedra, P.A., Maresso, A.W., Hopkins, L., 2020. Wastewater Analysis of SARS-CoV-2 as a Predictive Metric of Positivity Rate for a Major Metropolis. medRxiv 2020.11.04.20226191. https://doi.org/10/ghjmm9

Torii, S., Furumai, H., Katayama, H., 2020. Applicability of polyethylene glycol precipitation followed by acid guanidinium thiocyanate-phenol-chloroform extraction for the detection of SARS-CoV-2 RNA from municipal wastewater. Sci. Total Environ. 143067. https://doi.org/10/ghg84r

Tromberg, B.J., Schwetz, T.A., Pérez-Stable, E.J., Hodes, R.J., Woychik, R.P., Bright, R.A., Fleurence, R.L., Collins, F.S., 2020. Rapid Scaling Up of Covid-19 Diagnostic Testing in the United States — The NIH RADx Initiative. N. Engl. J. Med. 383, 1071-1077. https://doi.org/10.1056/NEJMsr2022263

U.S. Census Bureau, 2019. 2019 American Community Survey.

Westhaus, S., Weber, F.-A., Schiwy, S., Linnemann, V., Brinkmann, M., Widera, M., Greve, C., Janke, A., Hollert, H., Wintgens, T., Ciesek, S., 2021. Detection of SARS-CoV-2 in raw 
medRxiv preprint doi: https://doi.org/10.1101/2020.11.27.20238980; this version posted November 30, 2020. The copyright holder for this preprint (which was not certified by peer review) is the author/funder, who has granted medRxiv a license to display the preprint in perpetuity.

It is made available under a CC-BY-NC-ND 4.0 International license .

726

727

728

729

730

731

732

733

734

735

736

737

738

739

740

741

742

743

744

745

746

747

and treated wastewater in Germany - Suitability for COVID-19 surveillance and potential transmission risks. Sci. Total Environ. 751, 141750.

https://doi.org/10.1016/j.scitotenv.2020.141750

Wölfel, R., Corman, V.M., Guggemos, W., Seilmaier, M., Zange, S., Müller, M.A., Niemeyer, D., Jones, T.C., Vollmar, P., Rothe, C., Hoelscher, M., Bleicker, T., Brünink, S.,

Schneider, J., Ehmann, R., Zwirglmaier, K., Drosten, C., Wendtner, C., 2020. Virological assessment of hospitalized patients with COVID-2019. Nature 581, 465-469. https://doi.org/10.1038/s41586-020-2196-x

Wu, F., Zhang, J., Xiao, A., Gu, X., Lee, W.L., Armas, F., Kauffman, K., Hanage, W., Matus, M., Ghaeli, N., Endo, N., Duvallet, C., Poyet, M., Moniz, K., Washburne, A.D., Erickson, T.B., Chai, P.R., Thompson, J., Alm, E.J., 2020. SARS-CoV-2 Titers in Wastewater Are Higher than Expected from Clinically Confirmed Cases. mSystems 5. https://doi.org/10/gg5tgt

Yamamoto, K.R., Alberts, B.M., Benzinger, R., Lawhorne, L., Treiber, G., 1970. Rapid bacteriophage sedimentation in the presence of polyethylene glycol and its application to large-scale virus purification. Virology 40, 734-744. https://doi.org/10.1016/00426822(70)90218-7

Ye, Y., Ellenberg, R.M., Graham, K.E., Wigginton, K.R., 2016. Survivability, Partitioning, and Recovery of Enveloped Viruses in Untreated Municipal Wastewater. Environ. Sci. Technol. 50, 5077-5085. https://doi.org/10/ggt7br

Zhu, N., Zhang, D., Wang, W., Li, X., Yang, B., Song, J., Zhao, X., Huang, B., Shi, W., Lu, R., Niu, P., Zhan, F., Ma, X., Wang, D., Xu, W., Wu, G., Gao, G.F., Tan, W., 2020. A Novel 
medRxiv preprint doi: https://doi.org/10.1101/2020.11.27.20238980; this version posted November 30, 2020. The copyright holder for this preprint (which was not certified by peer review) is the author/funder, who has granted medRxiv a license to display the preprint in perpetuity. It is made available under a CC-BY-NC-ND 4.0 International license. 
medRxiv preprint doi: https://doi.org/10.1101/2020.11.27.20238980; this version posted November 30, 2020. The copyright holder for this preprint (which was not certified by peer review) is the author/funder, who has granted medRxiv a license to display the preprint in perpetuity.

It is made available under a CC-BY-NC-ND 4.0 International license .

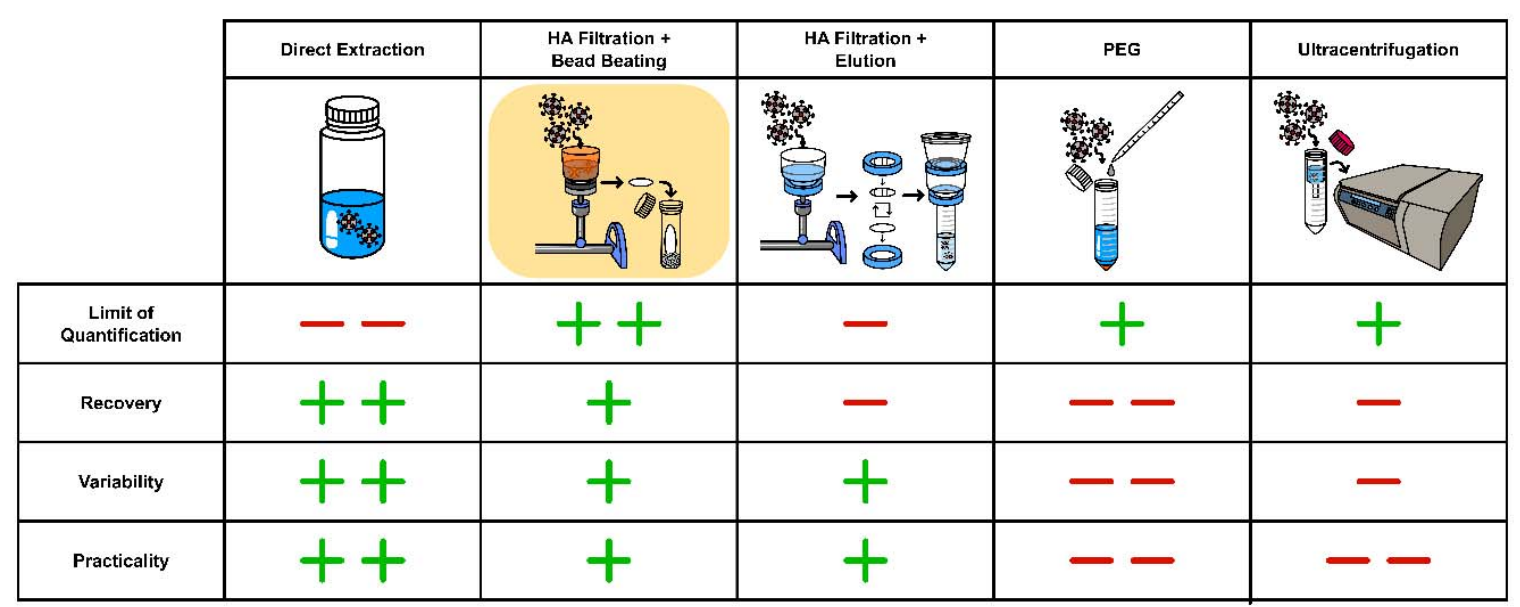

Estimates of the relative relationship of the five concentration methods to each other based on different performance characteristics. 
medRxiv preprint doi: https://doi.org/10.1101/2020.11.27.20238980; this version posted November 30, 2020. The copyright holder for this preprint (which was not certified by peer review) is the author/funder, who has granted medRxiv a license to display the preprint in perpetuity.

It is made available under a CC-BY-NC-ND 4.0 International license .

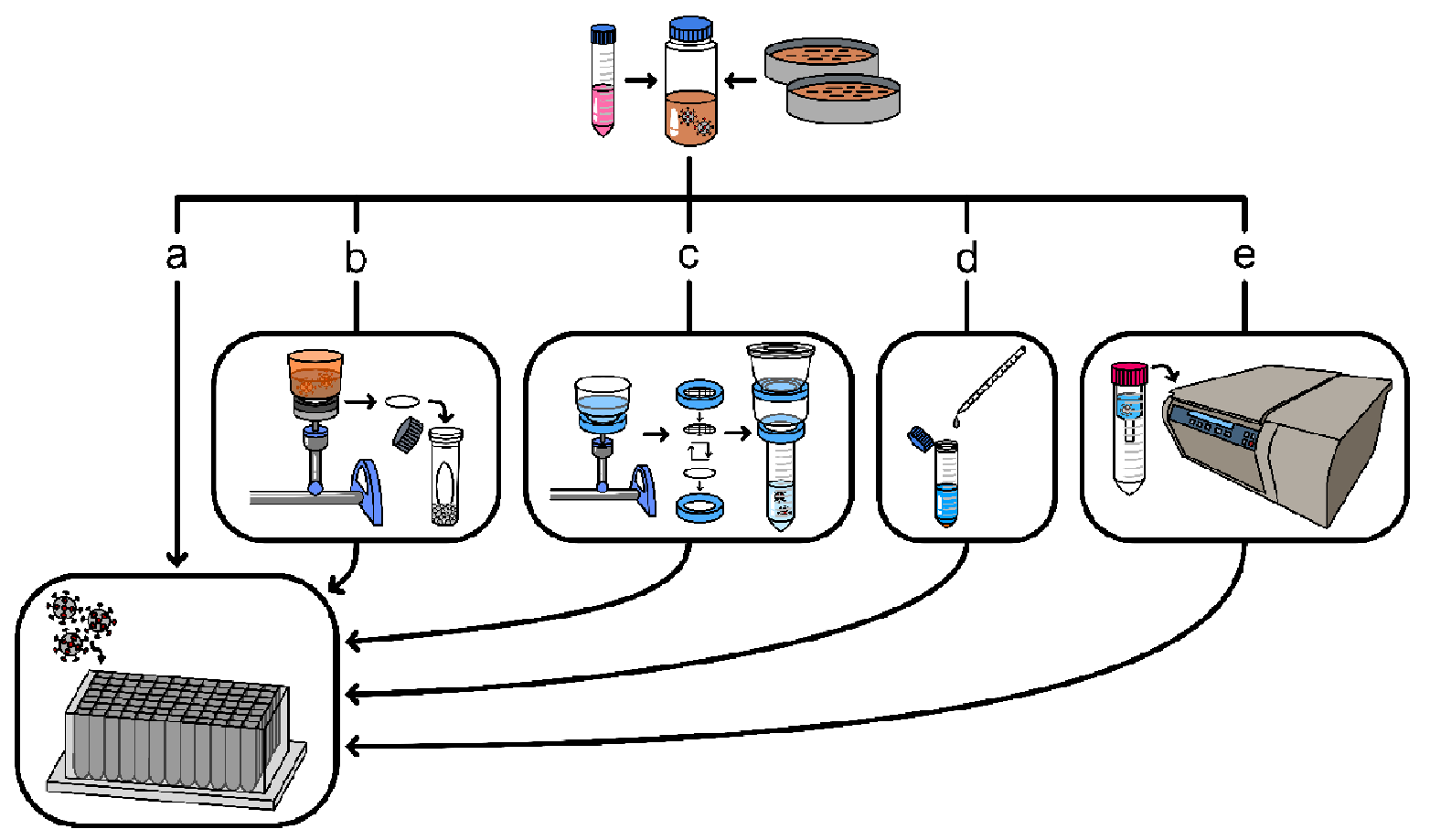

Figure 1: Overview of the evaluated concentration methods. Wastewater samples were

collected from several wastewater treatment plants across Houston in sample collection bottles and immediately spiked with BCoV(top). a-e): The samples were then concentrated through several methods: a) direct extraction, b) HA filtration with bead beating, c) HA filtration with elution, d) PEG precipitation, and e) ultrafiltration. All concentrated samples subsequently underwent RNA extraction. Samples undergoing direct extraction were not concentrated and instead were directly extracted from the liquid phase of the wastewater samples. 


\section{A} SARS-CoV-2 N1

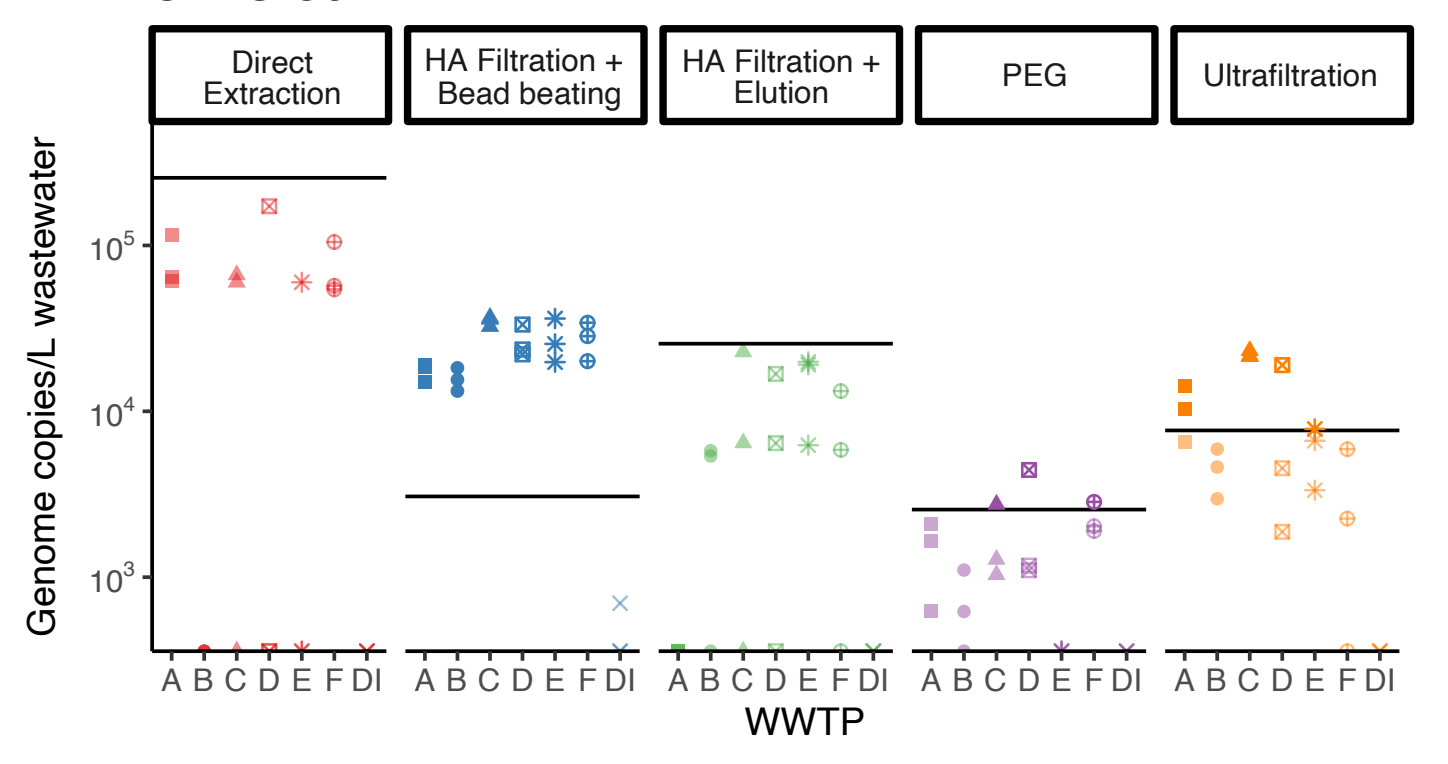

C

SARS-CoV-2 N1

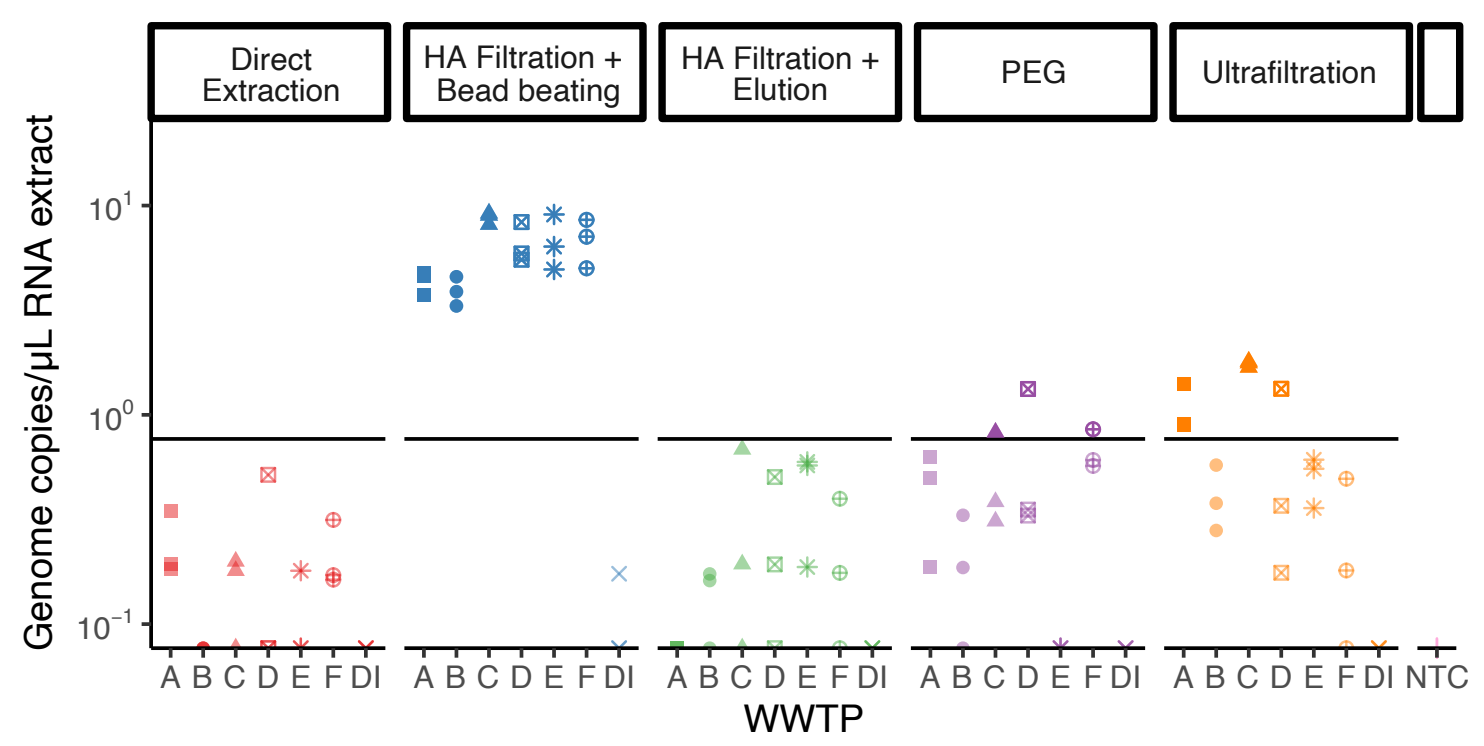

B

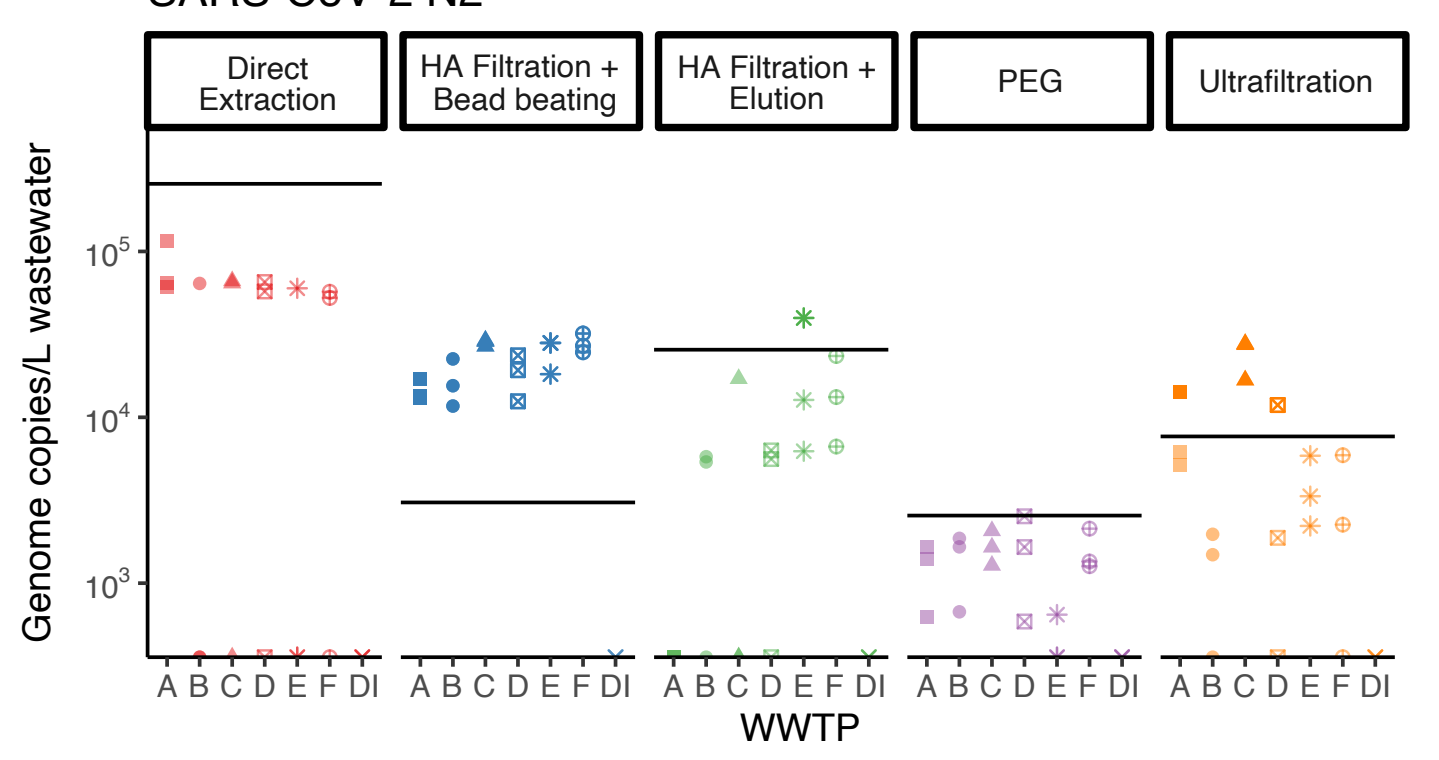

D

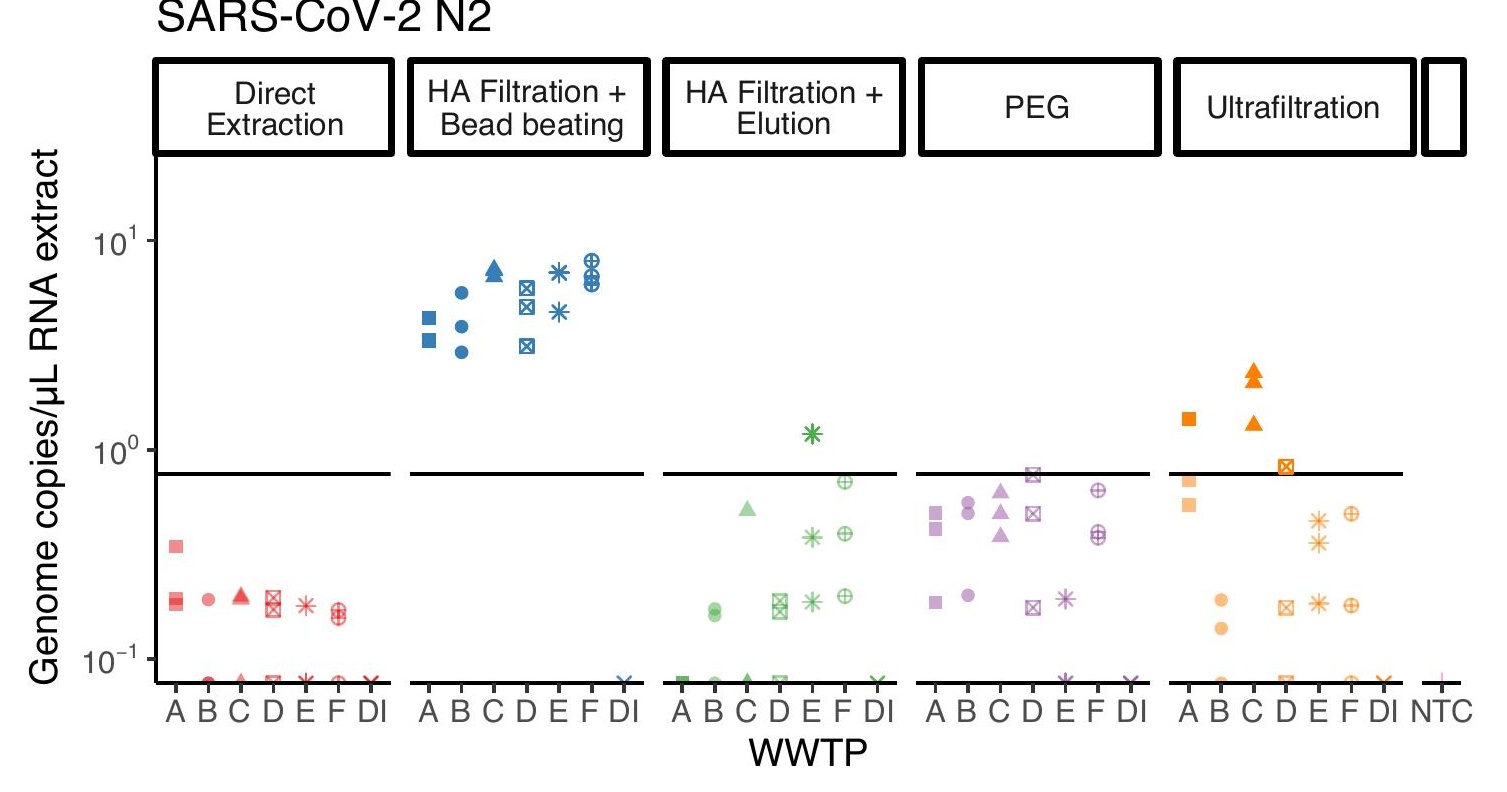


medRxiv preprint doi: https://doi.org/10.1101/2020.11.27.20238980; this version posted November 30, 2020. The copyright holder for this preprint (which was not certified by peer review) is the author/funder, who has granted medRxiv a license to display the preprint in perpetuity. It is made available under a CC-BY-NC-ND 4.0 International license .

Figure 2. SARS-CoV-2 RNA Concentrations. N1 (a) and N2 (b) gene target concentrations determined using different concentration methods for six wastewater samples reported in gene copies/L wastewater. $N 1(c)$ and $N 2(d)$ gene target concentrations determined using different concentration methods for six wastewater samples reported in gene copies/uL RNA template. Black horizontal lines indicate LoQs. WWTP are A-E, DI is deionized water, and NTC is no template control. 


\section{A}

Surrogate virus (BCoV)

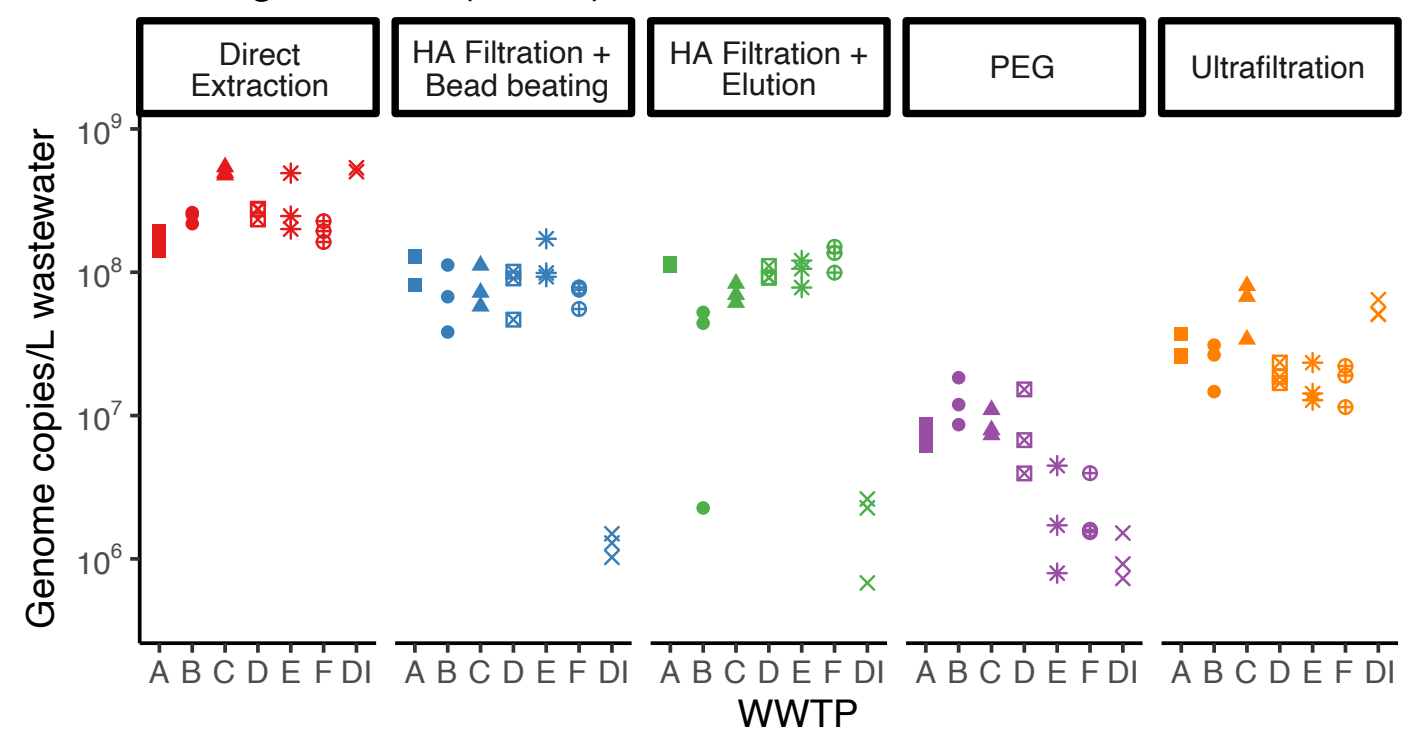

C

Surrogate virus (BCoV)

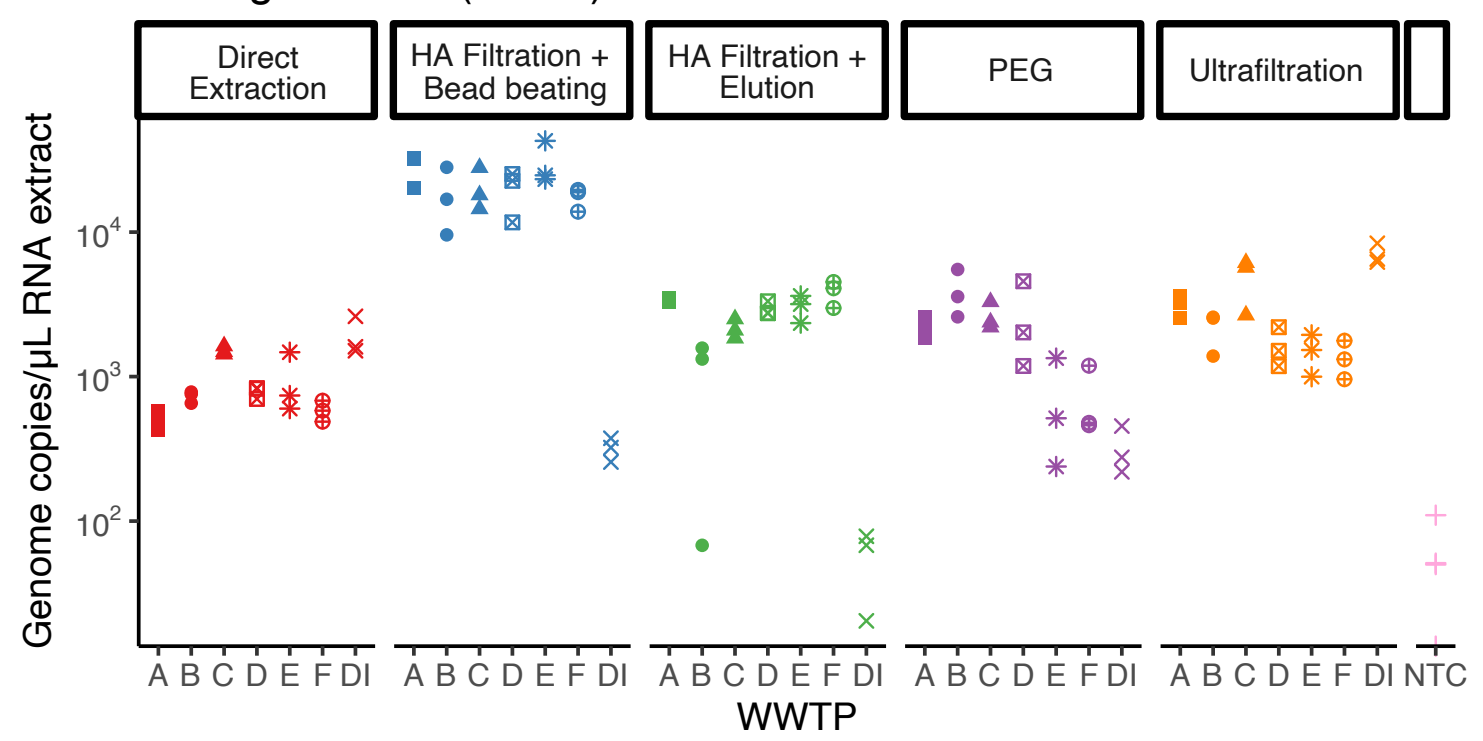

B

Pepper Mild Mottle Virus (PMMoV)

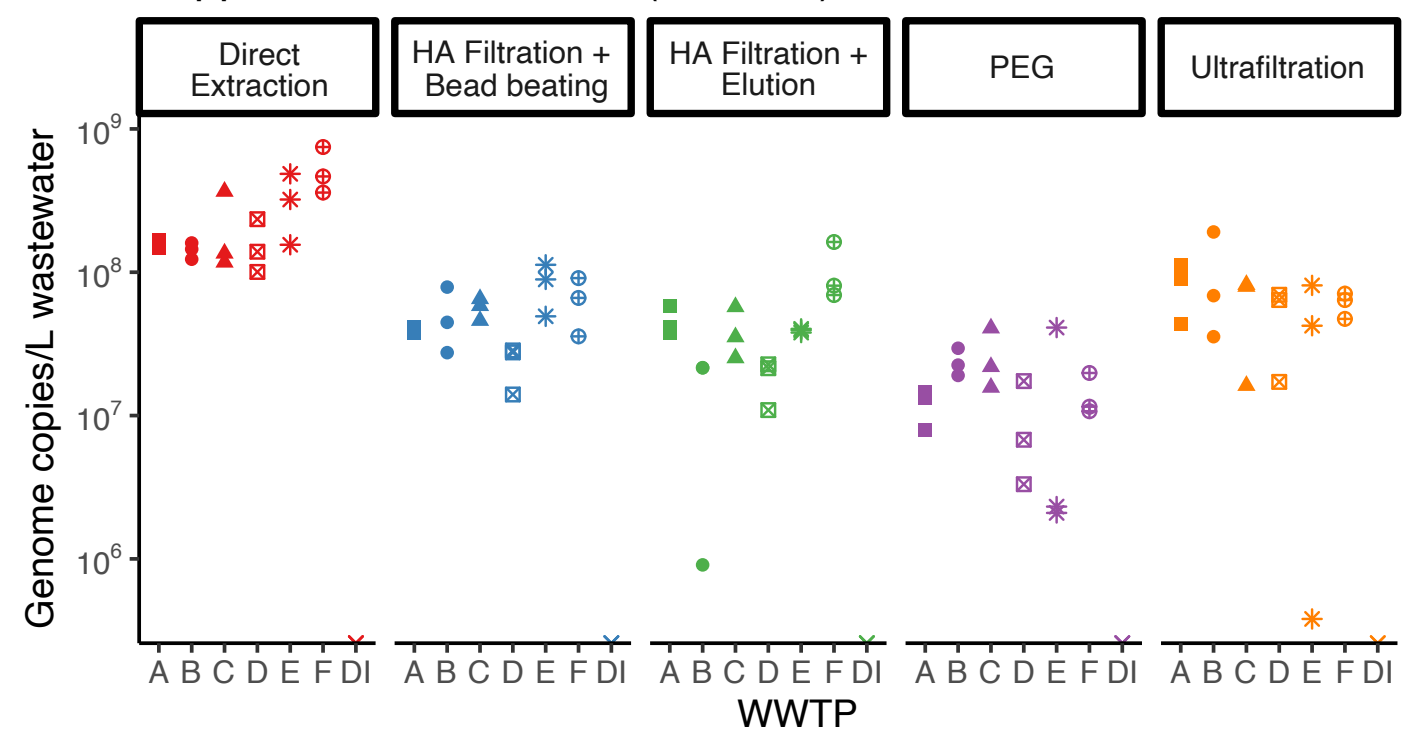

D

Pepper Mild Mottle Virus (PMMoV)

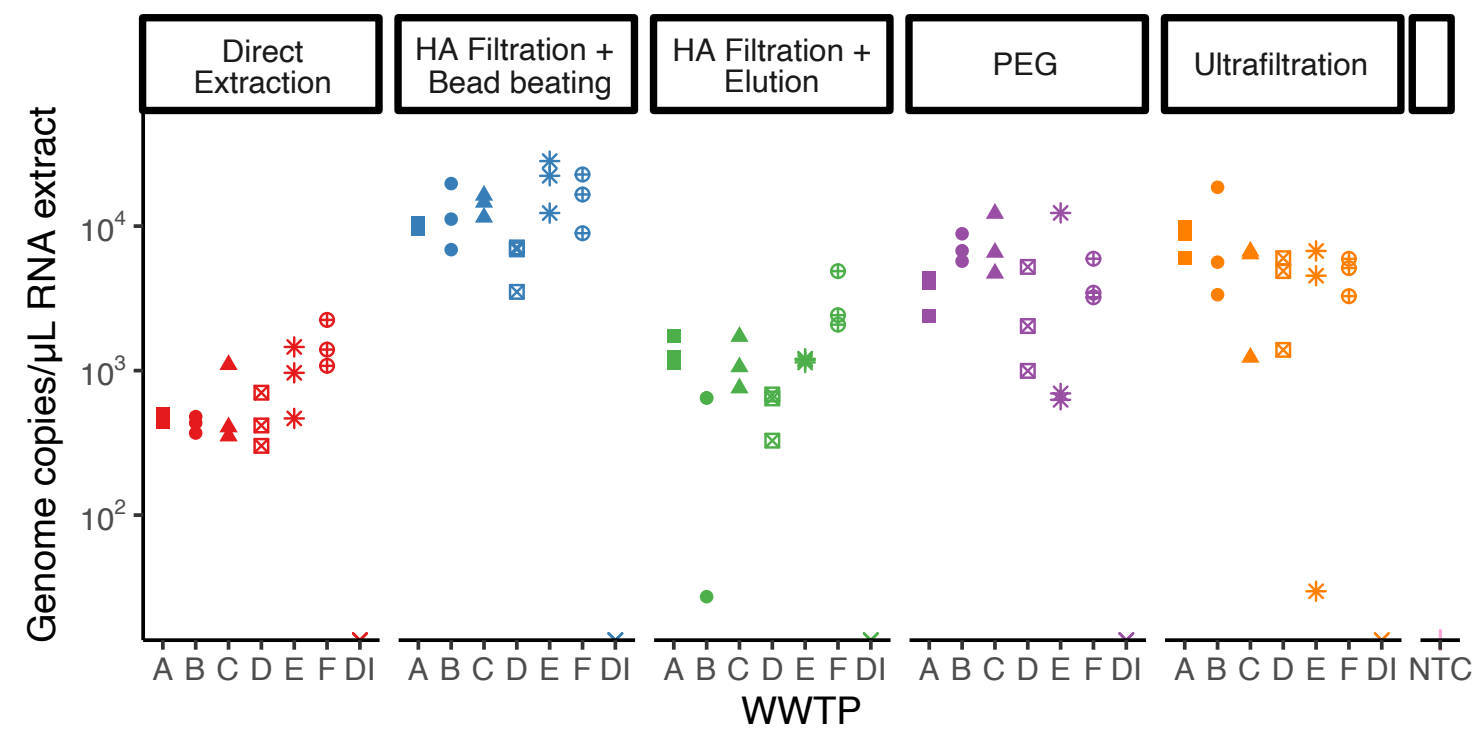


medRxiv preprint doi: https://doi.org/10.1101/2020.11.27.20238980; this version posted November 30, 2020. The copyright holder for this preprint (which was not certified by peer review) is the author/funder, who has granted medRxiv a license to display the preprint in perpetuity. It is made available under a CC-BY-NC-ND 4.0 International license .

Figure 3. BCoV and pMMoV concentrations. Recovery of $B C o V(a)$ and $p M M o V(b)$ between different concentration methods and different WWTP reported in gene copies/L wastewater. Recovery of $B C \mathrm{CoV}(\mathrm{c})$ and $\mathrm{pMMoV}(\mathrm{d})$ between different concentration methods and different WWTP reported in gene copies/ $\mu L$ RNA template. WWTP are A-E, DI is deionized water, and NTC is no template control. 